\title{
Teores e acúmulos de nutrientes em mudas de maracujazeiros sob salinidade hídrica e uso de urina de vaca
}

\author{
José Lucínio de Oliveira FREIRE ${ }^{1 *}$, Gislaine dos Santos NASCIMENTO ${ }^{1}$, \\ Ana Karoliny de Assis MEDEIROS ${ }^{1}$
}

${ }^{1}$ Instituto Federal de Educação, Ciência e Tecnologia da Paraíba, Picuí, PB, Brasil.

(Orcid: *; 0000-0002-6762-2416; 0000-0002-7696-0388)

*E-mail: prof.lucinio@gmail.com (Orcid: 0000-0002-0671-9185)

\begin{abstract}
Recebido em 05/05/2020; Aceito em 25/06/2020; Publicado em 31/07/2020.
RESUMO: A produção de mudas é uma das etapas mais importantes em sistemas produtivos de frutos, sendo a sua boa nutrição mineral um dos atributos que podem resultar em bom índice de qualidade. Objetivou-se avaliar a concentração e os acúmulos de macronutrientes e sódio em mudas de maracujazeiros produzidas com aplicação de urina de vaca e águas salinas. O experimento foi conduzido, em estufa de cobertura plástica, no Instituto Federal da Paraíba - campus Picuí, em delineamento experimental inteiramente casualizado, no arranjo fatorial $2 \times 2 \times 2$, correspondente a duas espécies de maracujazeiro (amarelo e roxo), dois níveis de condutividade elétrica da água de irrigação $\left(0,5 \mathrm{dS} \mathrm{m}^{-1}\right.$ e 3,5 dS m-1) e aplicação de urina oxidada de vaca a $0,0 \%$ e $5,0 \%$ e três repetições. Foram analisados os teores e os acúmulos de macronutrientes foliares $\left(\mathrm{N}, \mathrm{P}, \mathrm{K}^{+}, \mathrm{Ca}^{2+}\right.$, $\mathrm{Mg}^{2+}$ e S) e sódio. A irrigação com águas salinas de até 3,5 dS m $\mathrm{m}^{-1}$ produz efeitos negativos nos teores de $\mathrm{P}$ e $\mathrm{Na}^{+}$e positivos na concentração de $\mathrm{N}, \mathrm{Ma}^{2+}$ nos tecidos foliares de mudas de maracujazeiros amarelo e roxo. Os teores foliares de $\mathrm{N}, \mathrm{Mg}^{2+}$ e $\mathrm{Na}^{+}$em mudas de maracujazeiro-amarelo são superiores aos de maracujazeiroroxo A aplicação de urina oxidada de vaca diluída em água a 5,0\% na produção de mudas de maracujazeiros amarelo e roxo irrigadas com águas de elevada salinidade, por apresentar efeitos negativos nos teores de $\mathrm{K}^{+}$ nos tecidos foliares, indica que o insumo pode não eliminar os efeitos dos sais às plantas na fase de mudas. $\mathrm{O}$ uso de urina oxidada de vaca afeta, positivamente, os teores foliares de $\mathrm{N}$ em mudas de maracujazeiros. $\mathrm{O}$ acúmulo de macronutrientes $\left(\mathrm{P}, \mathrm{K}^{+}\right.$e $\mathrm{Ca}^{2+}$ ) em folhas de mudas de maracujazeiros é maior quando irrigadas com águas de baixa salinidade.
\end{abstract}

Palavras-chave: Passiflora spp; estresse salino; nutrição de plantas.

\section{Nutrients contents and accumulations in passion fruit seedlings under water salinity and use of cow urine}

\begin{abstract}
Seedling production is one of the most important stages in fruit production systems, and its good mineral nutrition is one of the attributes that can result in a good quality index. The objective was to evaluate the concentration and accumulations of macronutrients and sodium in passion fruit seedlings produced with the application of cow urine and saline water. The experiment was carried out in a plasticcovered greenhouse at the Federal Institute of Paraíba - Picuí campus, Brazil, in a completely randomized experimental design, in a $2 \times 2 \times 2$ factorial arrangement, corresponding to two species of passion fruit (yellow and purple), two levels of electrical conductivity of irrigation water $\left(0.5 \mathrm{dS} \mathrm{m}^{-1}\right.$ and $\left.3.5 \mathrm{dS} \mathrm{m}^{-1}\right)$ and application of oxidized cow urine at $0.0 \%$ and $5.0 \%$ and three repetitions. The levels and accumulations of leaf macronutrients $\left(\mathrm{N}, \mathrm{P}, \mathrm{K}^{+}, \mathrm{Ca}^{2+}, \mathrm{Mg}^{2+}\right.$ and $\mathrm{S}$ ) and sodium were analyzed. Irrigation with saline water up to 3.5 $\mathrm{dS} \mathrm{m}^{-1}$ produces negative effects on the levels of $\mathrm{P}$ and $\mathrm{Na}^{+}$and positive on the concentration of $\mathrm{N}, \mathrm{Ma}^{2+}$ in the leaf tissues of yellow and purple passion fruit seedlings. The leaf contents of $\mathrm{N} \mathrm{Mg}^{2+}$ and $\mathrm{Na}^{+}$in yellow passion fruit seedlings are higher than those of purple passion fruit. The application of oxidized cow urine diluted in $5.0 \%$ water in the production of yellow and purple passion fruit seedlings irrigated with water high salinity, due to its negative effects on $\mathrm{K}^{+}$content in leaf tissues, indicates that the input may not eliminate the effects of salts on plants in the seedling phase. The use of oxidized cow urine positively affects leaf $\mathrm{N}$ levels in passion fruit seedlings. The accumulation of macronutrients $\left(\mathrm{P}, \mathrm{K}^{+}\right.$and $\left.\mathrm{Ca}^{2+}\right)$ in leaves of passion fruit seedlings is greater when irrigated with low salinity water.
\end{abstract}

Keywords: Passiflora spp; salt stress; plant nutrition.

\section{INTRODUÇÃO}

O maracujazeiro pertence à família Passifloracea, originário da América Tropical, possuindo mais de 150 espécies utilizadas para diversas finalidades, desde alimentícias, medicinais, até ornamentais. As espécies mais cultivadas no Brasil, e no mundo, são de maracujá-amarelo
(Passiflora edulis f. flavicarpa), maracujá-roxo ( $P$. edulis) e maracujá-doce ( $P$. alata), sendo a espécie de maracujáamarelo ou azedo a que representa a quase totalidade do volume comercializado mundialmente (PIRES et al., 2011).

O Brasil é considerado o maior produtor desta frutífera, obtendo, no ano de 2018, uma produção de 602.651 
toneladas e um rendimento médio de $14,103 \mathrm{~kg} \mathrm{ha}^{-1}$ (IBGE, 2018). Entretanto, a produtividade nacional desta frutífera ainda é considerada baixa, tendo em vista a capacidade desta planta de produzir até $50 \mathrm{~kg} \mathrm{ha}{ }^{-1}$ (MIYAKE, 2016). Porém, na região Nordeste do Brasil, essa baixa eficiência produtiva pode estar relacionada com baixa qualidade do material biológico e de mudas, ausência de manejo adequado, adubações ineptas e uso de águas com conteúdo de sais acima do requerido pelas plantas.

A salinidade é um estresse ambiental que limita o crescimento e desenvolvimento das plantas e interfere, por conseguinte, no estado nutricional das mesmas (ASSAHA et al., 2013; OYENTUNJI; IMADE, 2015), independente do estádio, se muda ou planta adulta. Isso é decorrente de processos naturais ou antrópicos, tais como a irrigação e a fertilização (ONODERA et al., 2019).

De um modo geral, a salinidade inibe o crescimento das plantas, por meio dos efeitos osmótico e iônico que restringem a absorção de água e dos elementos essenciais (TANAKA et al., 2018). Os efeitos do excesso de sais solúveis na solução do solo, principalmente o $\mathrm{Na}^{+}$e o $\mathrm{Cl}^{-}$, provocam redução do desenvolvimento vegetal, atribuído devido ao efeito osmótico, provocado pela redução do potencial osmótico; desbalanço nutricional em função da elevada concentração iônica e a inibição da absorção de outros cátions pelo sódio e o efeito tóxico dos íons de sódio e cloreto. A magnitude dos danos depende do tempo, concentração, tolerância da cultura e volume de água transpirado (SCHOSSLER et al., 2012).

Para Cruz et al. (2006), o maracujazeiro-amarelo se comporta como moderadamente tolerante aos sais, ao passo que, para Cavalcante et al. (2009), durante a formação das mudas, o maracujazeiro-amarelo não tolera nível de salinidade da água superior a $1,0 \mathrm{dS} \mathrm{m}^{-1}$ (moderadamente sensível).

No tocante ao estado nutricional, em condições de exposição salina, ocorrem tendências de que as plantas apresentem decréscimos nos teores foliares de macronutrientes (SCHOSSLER et al., 2012). Para Olfa et al., 2018) isto pode estar relacionado ao excesso de sais solúveis na zona radicular, com redução na matéria seca caulinar e radicular em razão de menor absorção de água, que pode restringir a absorção de alguns elementos pelas plantas, principalmente $\mathrm{K}^{+}$e $\mathrm{Ca}^{2+}$, acarretando, em muitos dos casos, em deficiências nutricionais.

Em se tratando do uso de substâncias orgânicas, pouca ênfase tem sido dada à utilização de urina oxidada de vaca como provável suplemento nutricional das espécies cultivadas em condições de estresse salino. Conforme Araújo et al. (2019), a urina de vaca não elimina, mas mitiga os danos causados pelos sais da água sobre o crescimento e biomassa caulinar e radicular de plantas.

Diante do exposto, ressalta-se a necessidade de mais pesquisas envolvendo o uso de águas salinas e urina oxidada de vaca sobre a nutrição mineral do maracujazeiro, principalmente em estágio inicial, já que o bom estabelecimento da cultura no campo está a depender da qualidade final da muda.

Com isso, este trabalho objetivou avaliar os teores e acúmulos de macronutrientes em mudas de maracujazeiros amarelo e roxo irrigadas com águas salinas e aplicação concomitante de urina oxidada de vaca.

\section{MATERIAL E MÉTODOS}

A pesquisa foi realizada em estufa com filme plástico de 150 micras (filme leitoso) e cortinas laterais de tela branca, com $50 \%$ de sombreamento, instalada sob as coordenadas geográfica de $6^{\circ} 30^{\prime} 31^{\prime}$ "de latitude Sul e $36^{\circ} 21^{\prime} 49^{\prime \prime}$ de longitude Oeste, a $466 \mathrm{~m}$ de altitude, pertencente ao Instituto Federal de Educação, Ciência e Tecnologia da Paraíba, campus Picuí.

O experimento foi conduzido em delineamento inteiramente casualizado, em arranjo fatorial $2 \times 2 \times 2$, correspondente a duas espécies de maracujazeiro - o maracujazeiro-amarelo (Passiflora edulis f. flavicarpa Deg.) e o maracujazeiro-roxo ( $P$. edulis Sims) —, dois níveis de condutividade elétrica da água de irrigação $\left(0,5 \mathrm{dS} \mathrm{m}^{-1}\right.$ e 3,5 $\mathrm{dS} \mathrm{m}^{-1}$ ) e duas concentrações de urina oxidada de vaca diluída em água $(0,0 \%$ e $5,0 \%)$ e três repetições. As salinidades hídricas testadas se pautaram nas classificações de tolerância aos sais pelo maracujazeiro, conforme, respectivamente, Cruz et al. (2006) e Cavalcante et al. (2009).

O substrato utilizado era composto de uma mistura de um Neossolo Regolítico (Santos et al., 2018) de três partes dos primeiros $20 \mathrm{~cm}$ e uma parte de esterco bovino curtido, ambos, coletados no sítio Minador, município de Picuí, sendo submetido à análise química para determinação da fertilidade do solo (Tabela 1), conforme os critérios exigidos por Teixeira et al. (2017).

Tabela 1. Atributos químicos quanto à fertilidade do substrato utilizado no experimento.

Table 1. Chemical attributes regarding the fertility of the substrate used in the experiment.

\begin{tabular}{ll}
\hline Atributos & Valores \\
\hline $\mathrm{pH}\left(\mathrm{H}_{2} \mathrm{O}\right)$ & 7,60 \\
$\mathrm{P}\left(\mathrm{mg} \mathrm{dm}^{-3}\right)$ & 272,40 \\
$\mathrm{~K}^{+}\left(\mathrm{mg} \mathrm{dm}^{-3}\right)$ & 177,70 \\
$\mathrm{Na}^{+}\left(\mathrm{cmol}_{\mathrm{c}} \mathrm{dm}^{-3}\right)$ & 1,10 \\
$\mathrm{H}^{+}+\mathrm{Al}^{3+}\left(\mathrm{cmol}_{\mathrm{c}} \mathrm{dm}^{-3}\right)$ & 0,00 \\
$\mathrm{Al}^{3+}\left(\mathrm{cmol}_{\mathrm{c}} \mathrm{dm}^{-3}\right)$ & 0,00 \\
$\mathrm{Ca}^{2+}\left(\mathrm{cmol}_{\mathrm{c}} \mathrm{dm}^{-3}\right)$ & 2,53 \\
$\mathrm{Mg}^{2+}\left(\mathrm{cmol}_{\mathrm{c}} \mathrm{dm}^{-3}\right)$ & 1,04 \\
$\mathrm{M} . \mathrm{O} \cdot\left(\mathrm{g} \mathrm{kg}^{-1}\right)$ & 31,08 \\
\hline
\end{tabular}

Os níveis de condutividade elétrica das águas de irrigação foram obtidos com auxílio de condutivímetro digital, através da diluição de água de poço artesiano, fortemente salina $\left(\right.$ CEai $\left.=10,4 \mathrm{dSm}^{-1}\right)$ e água de baixa salinidade $($ CEai $=0,5$ $\mathrm{dS} \mathrm{m}^{-1}$ ), sendo caracterizadas, quimicamente, quanto à salinidade hídrica (RICHARDS, 1954), conforme evidenciado na Tabela 2.

A urina utilizada foi coletada de vacas em lactação, de rebanho leiteiro, sendo armazenada em galões plásticos devidamente desinfetados e mantidos lacrados por um período de quatro dias, antes da primeira aplicação (PESAGRO, 2002), com análises químicas determinadas conforme procedimentos metodológicos compilados por Carmo et al. (2000), conforme expressos na Tabela 3.

As mudas de maracujazeiros amarelo e roxo foram produzidas em recipientes de plástico (tubetes), com capacidade para armazenar $280 \mathrm{~cm}^{3}$ de solo, apostos $\mathrm{em}$ estruturas rígidas medindo $0,6 \mathrm{~m} \times 0,4 \mathrm{~m}$, e capacidade para 56 tubetes. Foram semeadas duas sementes por recipiente, sendo desbastada, cerca de 25 dias após a semeadura, a muda com menor atributo de crescimento. 
Tabela 2. Resultado da análise química quanto à salinidade das águas de irrigação utilizadas no experimento.

Table 2 . Result of the chemical analysis regarding the salinity of the irrigation water used in the experiment.

\begin{tabular}{lccc}
\hline Atributos & $\begin{array}{c}\text { Baixa } \\
\text { salinidade }\end{array}$ & $\begin{array}{c}\text { Alta } \\
\text { salinidade }\end{array}$ & Poço \\
\hline $\mathrm{pH}\left(\mathrm{H}_{2} \mathrm{O}\right)$ & 6,9 & 7,4 & 7,3 \\
$\mathrm{C} . \mathrm{E} .\left(\mathrm{dS} \mathrm{m} \mathrm{m}^{-1}\right)$ & 0,5 & 3,5 & 10,42 \\
$\mathrm{SO}_{4}^{-2}\left(\mathrm{mg} \mathrm{L}^{-1}\right)$ & 1,15 & 5,93 & 18,63 \\
$\mathrm{Mg}^{+2}\left(\mathrm{mmol}_{\mathrm{c}} \mathrm{L}^{-1}\right)$ & 2,97 & 17,37 & 65,34 \\
$\mathrm{Na}^{+}\left(\mathrm{mmol}_{\mathrm{c}} \mathrm{L}^{-1}\right)$ & 1,99 & 9,82 & 33,49 \\
$\mathrm{~K}^{+}\left(\mathrm{mmol}_{\mathrm{c}} \mathrm{L}^{-1}\right)$ & 0,06 & 0,33 & 1,65 \\
$\mathrm{Ca}^{+2}\left(\mathrm{mmol}_{\mathrm{c}} \mathrm{L}^{-1}\right)$ & 0,97 & 5,77 & 19,29 \\
$\mathrm{CO}_{3}^{-2}\left(\mathrm{mmol}_{\mathrm{c}} \mathrm{L}^{-1}\right)$ & 0,00 & 0,00 & 0,00 \\
$\mathrm{HCO}_{3}^{-2}\left(\mathrm{mmol}_{\mathrm{c}} \mathrm{L}^{-1}\right)$ & 0,83 & 6,17 & 21,00 \\
$\mathrm{Cl}\left(\mathrm{mmol}_{\mathrm{c}} \mathrm{L}^{-1}\right)$ & 5,50 & 31,83 & 117,50 \\
$\mathrm{RAS}$ & 1,41 & 2,89 & 5,15 \\
$\mathrm{PST}(\%)$ & 0,82 & 2,91 & 5,96 \\
$\mathrm{Classificação}$ & $\mathrm{C}_{2} \mathrm{~S}_{1}$ & $\mathrm{C}_{4} \mathrm{~S}_{1}$ & $\mathrm{C}_{4} \mathrm{~S}_{2}$ \\
\hline
\end{tabular}

C.E. $=$ Condutividade Elétrica a $25^{\circ}$; RAS = Razão de Adsorção de Sódio PST $=$ Percentagem de Sódio Trocável.

Tabela 3. Resultado da análise química da urina oxidada de vaca utilizada no experimento.

Table 3. Result of chemical analysis of oxidized cow urine used in the experiment.

\begin{tabular}{lc}
\hline Atributos & Valores \\
\hline $\mathrm{C} . \mathrm{E} .\left(\mathrm{dS} \mathrm{m}^{-1}\right)$ & 5,70 \\
$\mathrm{~N}\left(\mathrm{~g} \mathrm{~kg}^{-1}\right)$ & 1,40 \\
$\mathrm{P}\left(\mathrm{g} \mathrm{kg}^{-1}\right)$ & 0,08 \\
$\mathrm{~K}^{+}\left(\mathrm{g} \mathrm{kg}^{-1}\right)$ & 3,41 \\
$\mathrm{Ca}^{2+}\left(\mathrm{g} \mathrm{kg}^{-1}\right)$ & 0,10 \\
$\mathrm{Mg}^{2+}\left(\mathrm{g} \mathrm{kg}^{-1}\right)$ & 0,58 \\
$\mathrm{Na}^{+}\left(\mathrm{mg} \mathrm{kg}^{-1}\right)$ & 2,06 \\
$\mathrm{Zn}^{2+}\left(\mathrm{mg} \mathrm{kg}^{-1}\right)$ & 0,40 \\
$\mathrm{Cu}^{2+}\left(\mathrm{mg} \mathrm{kg}^{-1}\right)$ & 0,10 \\
$\mathrm{Fe}^{3+}\left(\mathrm{mg} \mathrm{kg}^{-1}\right)$ & 1,50 \\
$\mathrm{Mn}^{2+}\left(\mathrm{mg} \mathrm{kg}^{-1}\right)$ & 0,10 \\
\hline
\end{tabular}

As dotações hídricas foram realizadas com uma frequência média de dois dias, utilizando-se $70 \mathrm{~mL}$ com adubação em cobertura com urina de vaca realizada a cada sete dias e na dosagem de $70 \mathrm{~mL}$ por aplicação. Para equacionar o fornecimento hídrico com os tratamentos sem a urina de vaca, concomitantemente, foram adicionados nestes, $70 \mathrm{~mL}$ de água da mesma condutividade elétrica do tratamento, conforme Freire; Nascimento (2018).

Aos 60 dias após a semeadura, quando as mudas já estavam aptas ao transplantio para o campo (PRADO et al., 2004), foram coletadas amostras do tecido vegetal das mudas de maracujazeiro para diagnose nutricional. As folhas foram secas em estufa de ventilação forçada, $165^{\circ} \mathrm{C}$, por 72 horas, sendo, posteriormente, pesadas em balança semianalítica e trituradas em moinho do tipo Willey.

Os teores de nitrogênio $(\mathrm{N})$ foram determinados por digestão com ácido sulfúrico e os demais nutrientes: fósforo $(\mathrm{P})$, potássio $\left(\mathrm{K}^{+}\right)$, cálcio $\left(\mathrm{Ca}^{2+}\right)$, magnésio $\left(\mathrm{Mg}^{2+}\right)$ e $\mathrm{S}$ por digestão nitroperclórica, sendo determinados por espectrofotometria de absorção atômica e espectofotometria de chama. Os teores foliares de sódio $\left(\mathrm{Na}^{+}\right)$foram determinados por fotometria de chama. Todas as análises do tecido vegetal foram realizadas conforme os procedimentos metodológicos compilados por Carmo et al. (2000).

Os acúmulos de macronutrientes no tecido foliar foram calculadas conforme equação adaptada de Filgueiras et al. (2002), em trabalhos com alfaces, e Laviola; Dias (2008) em avaliações feitas com pinhão-manso:
$\mathrm{AC}=\mathrm{MSF} \times \mathrm{TN} \times 10^{-3}$

em que: $\mathrm{AC}=$ acúmulo de macronutrientes $\left(\mathrm{mg}\right.$ planta $\left.{ }^{-1}\right)$; $\mathrm{MSF}=$ massa seca foliar $\left(\mathrm{g}\right.$ planta $\left.^{-1}\right) ; \mathrm{TN}=$ teores de macronutrientes foliares $\left(\mathrm{g} \mathrm{kg}^{-1}\right)$.

Os dados foram submetidos à análise de variância com comparações de médias feitas pelo teste $\mathrm{F}$ a $5 \%$ de probabilidade (FERREIRA, 2011).

\section{RESULTADOS}

A Tabela 4 apresenta o resumo das análises de variância, pelos quadrados médios, para os teores foliares de nitrogênio $(\mathrm{N})$, fósforo $(\mathrm{P})$ e potássio $\left(\mathrm{K}^{+}\right)$, observando-se que os teores foliares de $\mathrm{N}$ foram afetados isoladamente pelas cultivares, salinidade e uso de urina de vaca. A salinidade influenciou, isoladamente, os teores de $\mathrm{P}$ e, quantos aos teores de $\mathrm{K}^{+}$nos tecidos foliares das mudas, foi observada a interação cultivares $\mathrm{x}$ salinidade $\mathrm{x}$ urina.

Tabela 4. Resumo das análises de variância, pelo quadrado médio, referente aos teores de $\mathrm{N}, \mathrm{P}$ e $\mathrm{K}^{+}$em mudas de maracujazeiros amarelo e roxo em função do uso de águas salinas e urina oxidada de vaca.

Table 4. Summary of analysis of variance, by the mean square, referring to the levels of $\mathrm{N}, \mathrm{P}$ and $\mathrm{K}^{+}$in yellow and purple passion fruit seedlings according to the use of saline water and oxidized cow urine.

\begin{tabular}{lcccc}
\hline \multicolumn{5}{c}{ Quadrados Médios } \\
\hline \multicolumn{5}{c}{ Fonte de } \\
$\quad$ Variação & GL & $\mathrm{N}$ & $\mathrm{P}$ & $\mathrm{K}^{+}$ \\
\hline Cultivares (C) & 1 & $24,000^{* *}$ & $0,000001^{\mathrm{ns}}$ & $4,167^{* *}$ \\
Salinidade (S) & 1 & $73,500^{* *}$ & $0,667^{*}$ & $216,000^{* *}$ \\
Urina (U) & 1 & $20,167^{* *}$ & $0,167^{\mathrm{ns}}$ & $48,167^{* *}$ \\
C x S & 1 & $0,667^{\mathrm{ns}}$ & $0,000001^{\mathrm{ns}}$ & $6,000^{* *}$ \\
C x U & 1 & $2,667^{\mathrm{ns}}$ & $0,167^{\mathrm{ns}}$ & $1,500^{\mathrm{ns}}$ \\
S x U & 1 & $0,167^{\mathrm{ns}}$ & $0,167^{\mathrm{ns}}$ & $6,000^{* *}$ \\
C x S x U & 1 & $2,2 \mathrm{E}-0015^{\mathrm{ns}}$ & $0,167^{\mathrm{ns}}$ & $10,667^{* *}$ \\
Erro & 16 & 1,292 & 0,125 & 0,337 \\
Total & 23 & & & \\
\hline CV $(\%)$ & \multicolumn{5}{c}{11,2} \\
\hline
\end{tabular}

Os maiores teores de $\mathrm{N}$ foram observados no tecido foliar das mudas de maracujazeiro-roxo em comparação às do maracujazeiro-amarelo, com valores médios respectivos de 18,9 e 16,9 $\mathrm{g} \mathrm{kg}^{-1}$ (Figura 1).

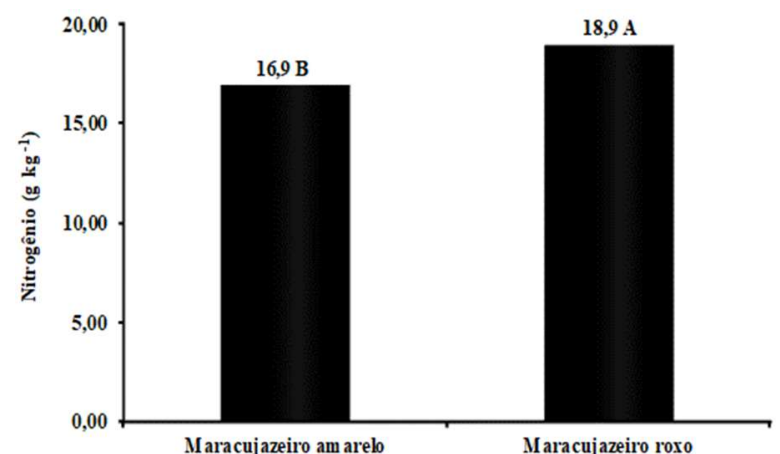

*Médias seguidas de mesmas letras não diferem entre si pelo teste $\mathrm{F}$ a $5 \%$ de significância.

Figura 1. Teores foliares de nitrogênio em mudas de maracujazeiroamarelo e roxo.

Figure 1. Leaf nitrogen content in yellow and purple passion fruit seedlings. 
Com a aplicação da urina oxidade de vaca diluída em água foram observados efeitos positivos nos teores de $\mathrm{N}$ nos tecidos foliares das mudas (Figura 2), bem como elevação com a irrigação com água de condutividade elétrica de 3,5 dS $\mathrm{m}^{-1}$ (Figura 3), apresentando acréscimos de $10,6 \%$ e $21,6 \%$ com uso do insumo orgânico e uso de água de alta salinidade, em comparação aos tratamentos sem o uso do insumo e água não salina, respectivamente.

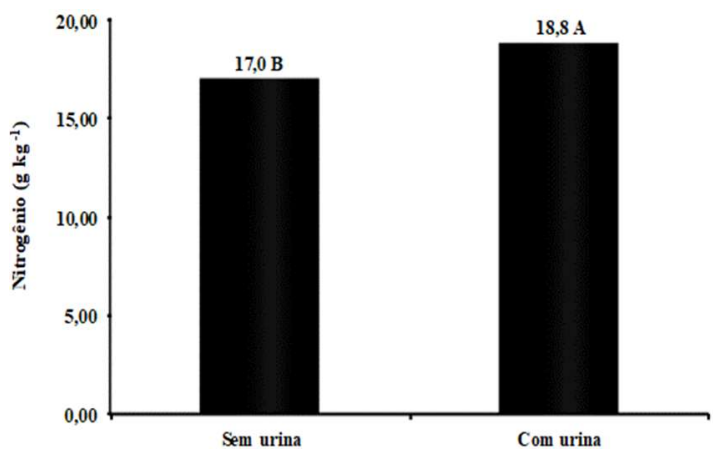

*Médias seguidas de mesmas letras não diferem entre si pelo teste $\mathrm{F}$ a 5\% de significância.

Figura 2. Teores foliares de nitrogênio em mudas de maracujazeiros com aplicação de urina oxidada de vaca.

Figure 2. Leaf nitrogen content in passion fruit seedlings with oxidized cow urine.

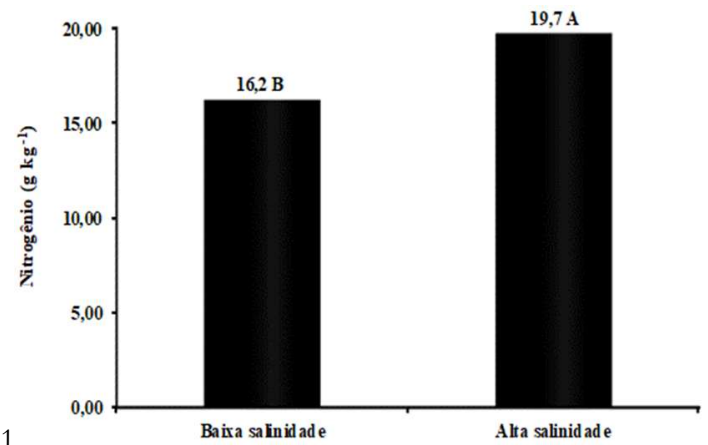

Médias seguidas de mesmas letras não diferem entre si pelo teste $\mathrm{F}$ a $5 \%$ de significância.

Figura 3. Teores foliares de nitrogênio em mudas de maracujazeiros irrigadas com águas salinas.

Figure 3. Leaf nitrogen content in passion fruit seedlings irrigated with saline water.

Conforme Scaramuzza et al. (2001) e Bertani et al. (2019), as mudas de maracujazeiro são supridas adequadamente com $\mathrm{N}$ quando o tecido foliar apresenta teores entre 21,0 e 26,0 g $\mathrm{kg}^{-1}$. Com isso, os resultados dos teores de $\mathrm{N}$ nos tecidos foliares das mudas de maracujazeiros (Figuras 1, 2 e 3) são deficitários.

Observou-se um decréscimo na ordem de 7,7\% nos teores de $\mathrm{P}$ no tecido foliar das mudas de maracujazeiros quando se utilizou irrigação com água de $3,5 \mathrm{dS} \mathrm{m}^{-1}$, sendo, respectivamente, de 3,25 e $3,00 \mathrm{~g} \mathrm{~kg}^{-1}$, quando irrigadas com águas de baixa $\left(0,5 \mathrm{dS} \mathrm{m}^{-1}\right)$ e alta salinidade $\left(3,5 \mathrm{dS} \mathrm{m}^{-1}\right)$ (Figura 4), resultados estes coerentes com os baixos teores deste elemento no substrato e na urina oxidada de vaca apresentados na Tabela 1.

No entanto, os teores de P observados, independentemente do teor salino da água de irrigação, foram inferiores aos 4,0 a 5,0 $\mathrm{g} \mathrm{kg}^{-1}$ e 3,8 $\mathrm{g} \mathrm{kg}^{-1}$ preconizados como adequados, respectivamente, por Malavolta et al.
(1997) e Scaramuzza et al. (2001). Mesmo com suprimento insuficiente em fósforo, as mudas de maracujazeiros não apresentaram sintomas visuais de deficiência.

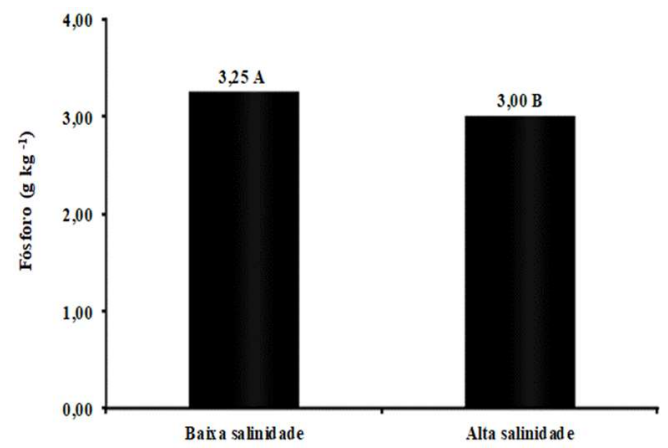

*Médias seguidas de mesmas letras não diferem entre si pelo teste $\mathrm{F}$ a $5 \%$ de significância.

Figura 4. Teores foliares de fósforo em mudas de maracujazeiros submetidas à irrigação com águas salinas.

Figure 4. Leaf phosphorus content in passion fruit seedlings submitted to irrigation with saline water.

Independentemente da espécie e do uso, ou não, da aplicação semanal de urina oxidada de vaca diluída em água, o aumento da condutividade elétrica da água de irrigação, de 0,5 para 3,5 dS m${ }^{-1}$, reduziu os teores foliares de potássio $\left(\mathrm{K}^{+}\right)$ nas mudas de maracujazeiro (Figura 5).

Sob condições de irrigação com água de maior teor salino $\left(3,5 \mathrm{dS} \mathrm{m}^{-1}\right)$, sem uso de urina oxidada de vaca, as mudas de maracujazeiros amarelo e roxo apresentaram, respectivamente, teores médios de $\mathrm{K}^{+}$nas folhas de 18,7 e $18,0 \mathrm{~g} \mathrm{~kg}^{-1}$, inferiores em 26,1\% $\left(25,3 \mathrm{~g} \mathrm{~kg}^{-1}\right)$ e $28,9 \%(25,3 \mathrm{~g}$ $\mathrm{kg}^{-1}$ ) aos observados sob condições de irrigação com água de baixa salinidade. $O$ resultado mais expressivo nos teores médios de $\mathrm{K}^{+}$foliar foi observado em mudas de maracujazeiro-amarelo irrigadas com água de baixa salinidade *0,5 dS m-1) e aplicação de urina oxidada de vaca.

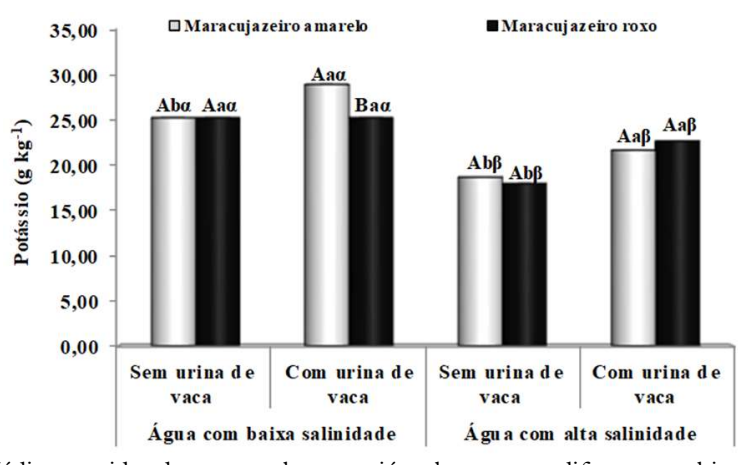

*Médias seguidas de mesmas letras maiúsculas entre as diferentes cultivares, mesma salinidade e mesma concentração de urina; mesmas letras minúsculas dentro da mesma cultivar, mesma salinidade e diferentes concentrações de urina; mesmas letras gregas dentro da mesma cultivar, entre diferentes salinidades e mesma concentração de urina não diferem entre si pelo teste $\mathrm{F}$ a $5 \%$ de significância.

Figura 5. Teores foliares de potássio em mudas de maracujazeiroamarelo e roxo, submetidas à aplicação de urina de vaca e irrigação com águas salinas.

Figure 5. Leaf potassium contents in yellow and purple passion fruit seedlings, submitted to the application of cow urine and irrigation with saline water.

Entretanto, ao avaliar os efeitos da aplicação de urina de vaca, sob condições de irrigação com água de alta salinidade, é possível verificar uma resposta positiva do uso deste 
insumo em aumentar os teores de $\mathrm{K}^{+}$no tecido foliar de ambas as espécies de maracujazeiros estudadas. Os teores foram elevados de 18,7 para $21,7 \mathrm{~g} \mathrm{~kg}^{-1}$ e de 18,0 para $22,7 \mathrm{~g}$ $\mathrm{kg}^{-1}$ para as cultivares de maracujazeiro-amarelo e roxo, respectivamente. As mudas de maracujazeiro não estavam supridas adequadamente em potássio, pois apresentaram teores nos tecidos foliares inferiores aos $37,0 \mathrm{~g} \mathrm{~kg}^{-1}$ indicados por Scaramuzza et al. (2001).

O resumo das análises de variância relativas aos teores de $\mathrm{Ca}^{2+}, \mathrm{Mg}^{2+}, \mathrm{S}$ e $\mathrm{Na}^{+}$encontram-se na Tabela 5. Nesta, percebe-se que os tratamentos não exerceram efeitos significativos nos teores foliares de $\mathrm{Ca}^{2+}$, sendo que os teores de $\mathrm{Mg}^{2+} \mathrm{e} \mathrm{Na}^{+}$foram afetados pelas cultivares e salinidade e os teores foliares de $\mathrm{S}$ sofreram influência isolada das cultivares analisadas.

Tabela 5. Resumo das análises de variância, pelo quadrado médio, referente aos teores de $\mathrm{Ca}^{2+}, \mathrm{Mg}^{2+}, \mathrm{S}$ e $\mathrm{Na}^{+}$em mudas de maracujazeiros amarelo e roxo em função do uso de águas salinas e urina oxidada de vaca.

Table 5. Summary of analysis of variance, by the mean square, referring to the levels of $\mathrm{Ca}^{2+}, \mathrm{Mg}^{2+}, \mathrm{S}$ and $\mathrm{Na}^{+}$in yellow and purple passion fruit seedlings according to the use of saline water and oxidized cow urine.

\begin{tabular}{|c|c|c|c|c|c|}
\hline \multicolumn{6}{|c|}{ Quadrados Médios } \\
\hline $\begin{array}{l}\text { Fontes de } \\
\text { Variação }\end{array}$ & GL & $\mathrm{Ca}^{2+}$ & $\mathrm{Mg}^{2+}$ & $\mathrm{S}$ & $\mathrm{Na}^{+}$ \\
\hline Cultivares (C) & 1 & $40,041^{\mathrm{ns}}$ & $3,375^{*}$ & $2,667^{*}$ & $2,178^{* *}$ \\
\hline Salinidade (S) & 1 & $77,041^{\mathrm{ns}}$ & $92,042^{* *}$ & $0,001^{\mathrm{ns}}$ & $95,960^{* *}$ \\
\hline Urina $(\mathrm{U})$ & 1 & $9,375^{\mathrm{ns}}$ & $0,042^{\mathrm{ns}}$ & $0,167^{\mathrm{ns}}$ & $0,362^{\mathrm{ns}}$ \\
\hline $\mathrm{C} \times \mathrm{S}$ & 1 & $63,375^{\mathrm{ns}}$ & $0,042^{\mathrm{ns}}$ & $2,667^{\mathrm{ns}}$ & $0,226^{\mathrm{ns}}$ \\
\hline $\mathrm{C} \times \mathrm{U}$ & 1 & $9,375^{\mathrm{ns}}$ & $0,375^{\mathrm{ns}}$ & $1,500^{\mathrm{ns}}$ & $0,122^{\mathrm{ns}}$ \\
\hline $\mathrm{S} \times \mathrm{U}$ & 1 & $0,042^{\mathrm{ns}}$ & $0,375^{\mathrm{ns}}$ & $0,167^{\mathrm{ns}}$ & $0,179^{\mathrm{ns}}$ \\
\hline $\mathrm{C} \times \mathrm{S} \times \mathrm{U}$ & 1 & $2,042^{\mathrm{ns}}$ & $0,375^{\mathrm{ns}}$ & $0,167^{\mathrm{ns}}$ & $0,116^{\mathrm{ns}}$ \\
\hline Erro & 16 & 26,667 & 0,583 & 0,500 & 0,238 \\
\hline Total & 23 & & & & \\
\hline $\mathrm{CV}(\%)$ & & 17,9 & 11,8 & 22,3 & 6,4 \\
\hline
\end{tabular}

Os tecidos foliares das mudas de maracujazeiro apresentaram teores médios de $\mathrm{Ca}^{2+}$ de $28,8 \mathrm{~g} \mathrm{~kg}^{-1}$, indepedc $\checkmark$ ndentemente dos tratamentos analisados. De acordo com Scaramuzza et al. (2001), pelos teores de $\mathrm{Ca}^{2+}$ observados, as mudas de maracujazeiro apresentaram-se adequadamente supridas com este elemento.

Conforme observado na Figura 6, as mudas de maracujazeiro-roxo apresentaram teores foliares de $\mathrm{Mg}^{2+}$ de $6,83 \mathrm{~g} \mathrm{~kg}^{-1}$, superiores em $12,3 \%$ aos observados no maracujazeiro-amarelo $\left(6,08 \mathrm{~g} \mathrm{~kg}^{-1}\right)$.

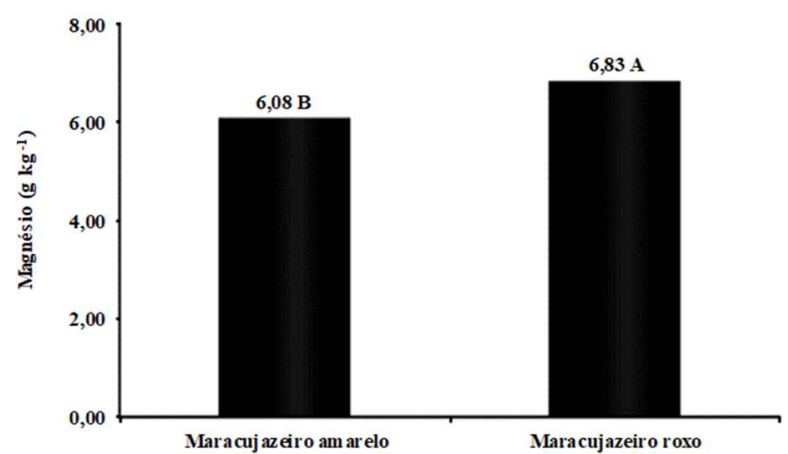

*Médias seguidas de mesmas letras não diferem entre si pelo teste $\mathrm{F}$ a $5 \%$ de significância.

Figura 6. Teores foliares de magnésio em mudas de maracujazeiros amarelo e roxo.

Figure 6. Leaf magnesium content in yellow and purple passion fruit seedlings.
A utilização de água de condutividade elétrica de 3,5 dS $\mathrm{m}^{-1}$ proporcionou às mudas de maracujazeiros maiores teores foliares de $\mathrm{Mg}^{2+}$ em comparação às irrigadas com água de 0,5 $\mathrm{dS} \mathrm{m} \mathrm{m}^{-1}$ (Figura 7). Os valores médios verificados nos tecidos foliares das mudas de maracujazeiros oscilaram de 4,50 a 8,41 $\mathrm{g} \mathrm{kg}^{-1}$, entre as plantas com dotação hídrica com águas de baixa e alta salinidade, respectivamente.

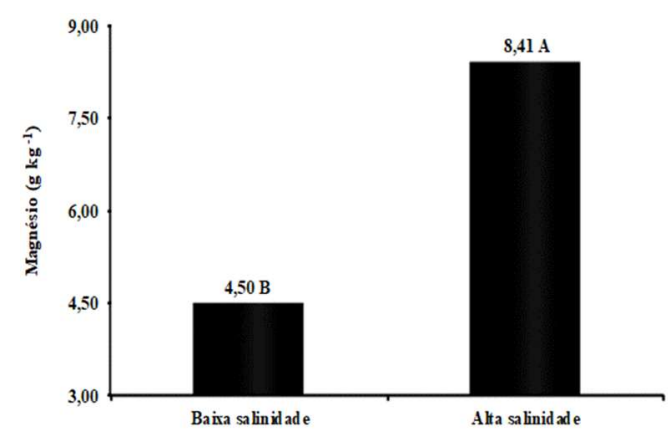

*Médias seguidas de mesmas letras não diferem entre si pelo teste $\mathrm{F}$ a 5\% de significância.

Figura 7. Teores foliares de magnésio no tecido foliar de mudas de maracujazeiros submetidas à irrigação com águas salinas.

Figure 7. Leaf magnesium content in the leaf tissue of passion fruit seedlings submitted to irrigation with saline water.

No que tange aos teores foliares de $\mathrm{S}$, estes foram observados em maior quantidade em mudas de maracujazeiro-amarelo $\left(3,50 \mathrm{~g} \quad \mathrm{~kg}^{-1}\right), \quad$ com $23,7 \%$ de superioridade em relação ao maracujazeiro-roxo $\left(2,83 \mathrm{~g} \mathrm{~kg}^{-1}\right)$, conforme a Figura 8.

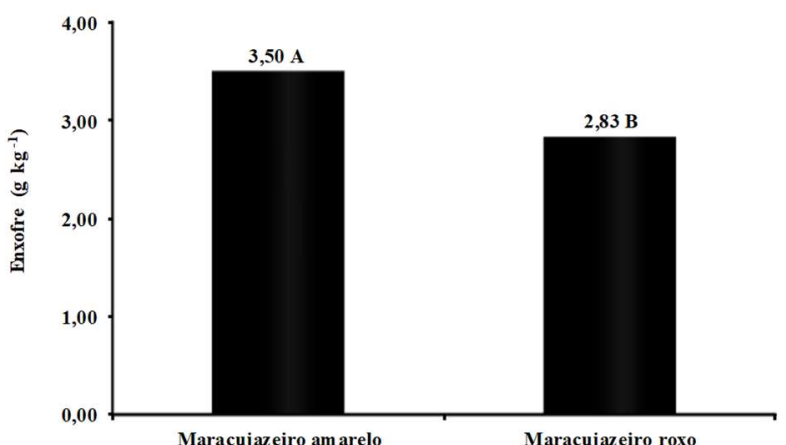

*Médias seguidas de mesmas letras não diferem entre si pelo teste $\mathrm{F}$ a $5 \%$ de significância.

Figura 8. Teores foliares de enxofre em mudas de maracujazeiroamarelo e roxo.

Figure 8. Leaf sulfur content in yellow and purple passion fruit seedlings

As mudas de maracujazeiro-roxo apreenderam, no tecido foliar, maior quantidade de $\mathrm{Na}^{+}$do que as de maracujazeiroamarelo, com valores médios de 9,0 e 8,0 g $\mathrm{kg}^{-1}$, respectivamente (Figura 9).

Verificaram-se, pela Figura 10, acréscimos de 100,6\% no teor de $\mathrm{Na}^{+}$no tecido foliar quando se utilizou água de alta salinidade $\left(3,5 \mathrm{dS} \mathrm{m}^{-1}\right)$, em comparação com plantas irrigadas com água menos salina $\left(0,5 \mathrm{dS} \mathrm{m}^{-1}\right)$, com valores médios respectivos de 11,7 e $5,83 \mathrm{~g} \mathrm{~kg}^{-1}$.

O resumo das análises de variância, pelos quadrados médios, para os acúmulos foliares de nitrogênio ( $\mathrm{ACN}$ ), de fósforo (ACP) e de potássio $\left(\mathrm{ACK}^{+}\right)$estão dispostos na Tabela 6. 
Freire et al.

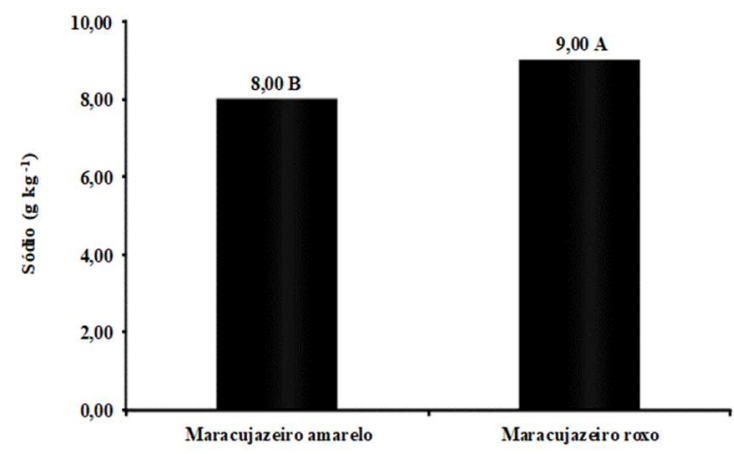

*Médias seguidas de mesmas letras não diferem entre si pelo teste $\mathrm{F}$ a 5\% de significância.

Figura 9. Teores foliares de sódio em tecidos foliares de mudas de maracujazeiros amarelo e roxo.

Figure 9. Leaf sodium content in leaf tissues of yellow and purple passion fruit seedlings

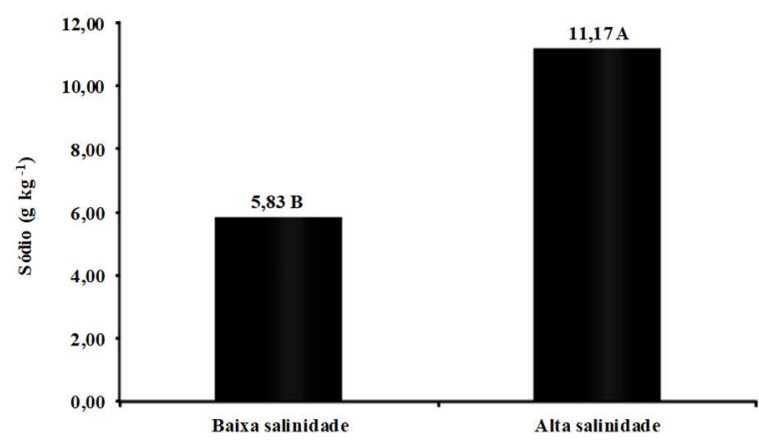

*Médias seguidas de mesmas letras não diferem entre si pelo teste $\mathrm{F}$ a $5 \%$ de significância.

Figura 10. Teores foliares de sódio em mudas de maracujazeiros submetidas à irrigação com águas salinas.

Figure 10. Leaf sodium content in passion fruit seedlings submitted to irrigation with saline water.

Tabela 6. Resumo das análises de variância, pelos quadrados médios, referente aos acúmulos foliares de nitrogênio (ACN), de fósforo (ACP) e de potássio $\left(\mathrm{ACK}^{+}\right)$em tecidos foliares de mudas de maracujazeiros amarelo e roxo em função do uso de águas salinas e urina oxidada de vaca.

Table 6. Summary of analysis of variance, by the mean square, referring leaf accumulations of nitrogen (ACN), phosphorus (ACP) and potassium $\left(\mathrm{ACK}^{+}\right)$in leaf tissues of yellow and purple passion fruit seedlings as a result of the use of saline water and oxidized cow urine.

\begin{tabular}{lcccc}
\hline \multicolumn{5}{c}{ Quadrados Médios } \\
\hline \multicolumn{5}{c}{ Fonte de } \\
Variação & GL & ACN & ACP & ACK $^{+}$ \\
\hline Cultivares (C) & 1 & $414,170^{* *}$ & $21,094^{* *}$ & $1152,320^{* *}$ \\
Salinidade (S) & 1 & $38,709^{\text {ns }}$ & $4,150^{*}$ & $903,563^{* *}$ \\
Urina (U) & 1 & $72,037^{\text {ns }}$ & $0,487^{\text {ns }}$ & $140,07^{\mathrm{ns}}$ \\
C x S & 1 & $2,802^{\text {ns }}$ & $0,577^{\mathrm{ns}}$ & $152,208^{\mathrm{ns}}$ \\
C x U & 1 & $16,040^{\mathrm{ns}}$ & $0,008^{\mathrm{ns}}$ & $33,610^{\mathrm{ns}}$ \\
S x U & 1 & $1,306^{\mathrm{ns}}$ & $0,273^{\mathrm{ns}}$ & $2,306^{\mathrm{ns}}$ \\
C x S x U & 1 & $2,089^{\mathrm{ns}}$ & $0,018^{\mathrm{ns}}$ & $15,649^{\mathrm{ns}}$ \\
Erro & 16 & 19,967 & 0,656 & 34,513 \\
Total & 23 & & & \\
\hline CV $(\%)$ & \multicolumn{5}{c}{29,9} & 29,7 \\
\hline
\end{tabular}

$\mathrm{Na}$ Figura 11, verifica-se que o acúmulo de $\mathrm{N}$ no tecido foliar das mudas de maracujazeiro-roxo $(10,03 \mathrm{mg})$ foi inferior ao observado no maracujazeiro-amarelo $(18,33 \mathrm{mg})$.

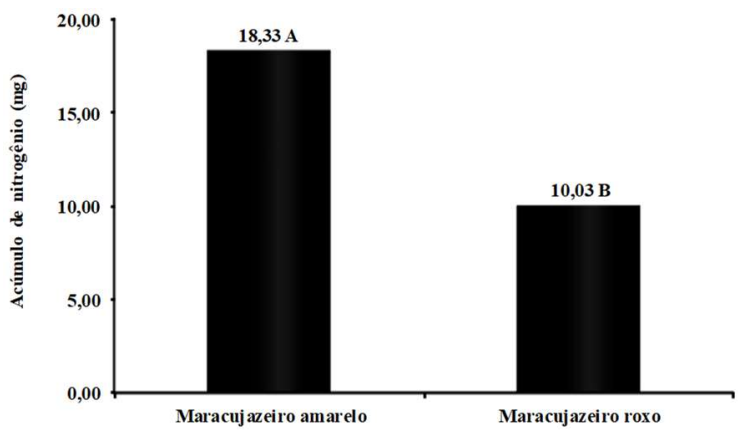

*Médias seguidas de mesmas letras não diferem entre si pelo teste $\mathrm{F}$ a $5 \%$ de significância.

Figura 11. Acúmulo de nitrogênio na matéria seca foliar de mudas de maracujazeiro-amarelo e roxo.

Figure 11. Nitrogen accumulation in leaf dry matter of yellow and purple passion fruit seedlings.

O acúmulo de P na matéria seca foliar seguiu a tendência de efeitos isolados nas espécies, sendo observados maiores acúmulos deste nutriente em mudas de maracujazeiroamarelo, superior em $106,2 \%$ ao verificado nas mudas de maracujazeiro-roxo (Figura 12).

Todavia, ao avaliar os efeitos isolados do acúmulo de $\mathrm{P}$ em relação ao uso de águas salinas, percebe-se que a adição

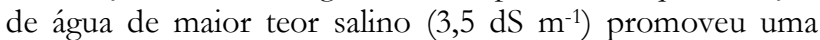
redução de $26,8 \%$ no acúmulo deste nutriente na matéria seca foliar das mudas de maracujazeiros, com redução de 3,13 a 2,29 mg (Figura 13), seguindo a tendência observada na Figura 4.

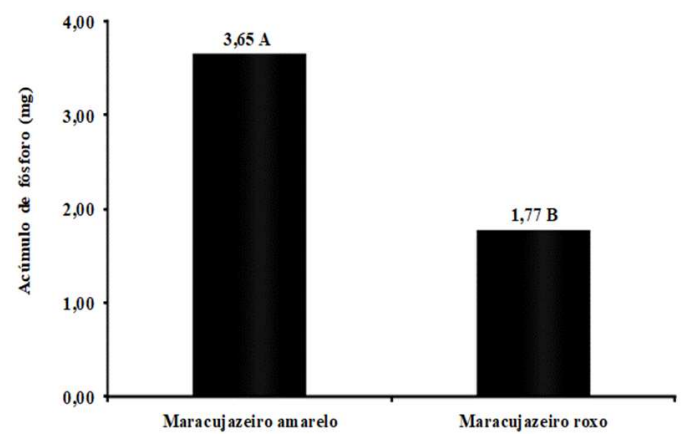

*Médias seguidas de mesmas letras não diferem entre si pelo teste $\mathrm{F}$ a 5\% de significância.

Figura 12. Acúmulo de fósforo na fitomassa seca foliar de mudas de maracujazeiro-amarelo e roxo.

Figure 12. Phosphorus accumulation in dry leaf phytomass of yellow and purple passion fruit seedlings.

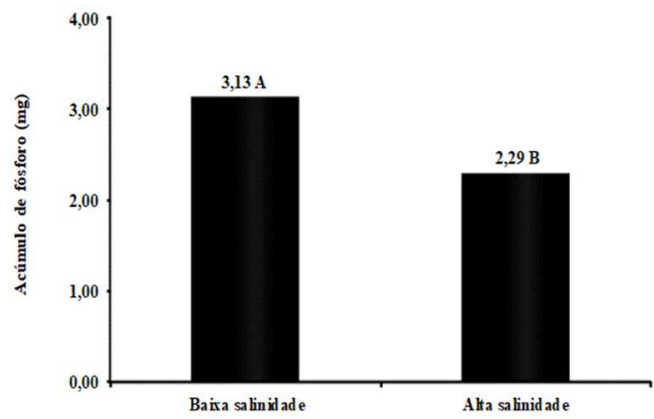

* Médias seguidas de mesmas letras não diferem entre si pelo teste $\mathrm{F}$ a $5 \%$ de significância.

Figura 13. Acúmulo de fósforo em mudas de maracujazeiros submetidas à irrigação com águas salinas.

Figure 13. Phosphorus accumulation in passion fruit seedlings submitted to irrigation with saline waters. 
De acordo com a Figura 14, as mudas de maracujazeiroamarelo apresentaram maiores valores médios de acúmulos de $\mathrm{K}^{+}(26,72 \mathrm{mg})$, superior em 107,8\% aos obtidos na cultivar de maracujazeiro-roxo $(12,86 \mathrm{mg})$.

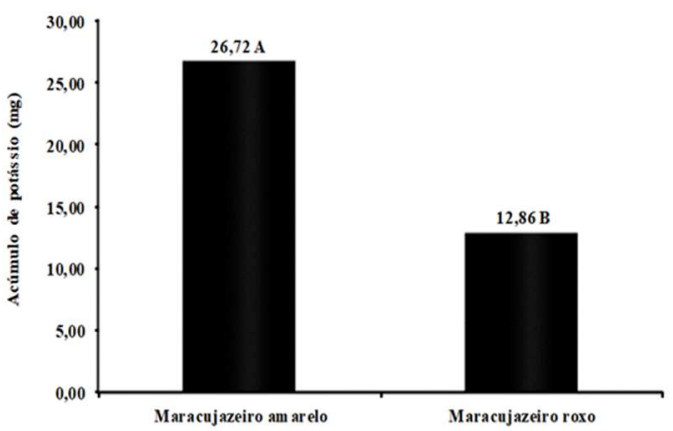

*Médias seguidas de mesmas letras não diferem entre si pelo teste $\mathrm{F}$ a $5 \%$ de significância.

Figura 14. Acúmulo de potássio na matéria seca foliar de mudas de maracujazeiros amarelo e roxo.

Figure 14. Potassium accumulation in leaf dry matter of yellow and purple passion fruit seedlings.

Com relação à utilização de água de maior $\left(3,5 \mathrm{dS} \mathrm{m}^{-1}\right)$ e menor teor salino $\left(0,5 \mathrm{dS} \mathrm{m}^{-1}\right)$, e conforme observado na
Figura 15, ocorreu uma redução do $\mathrm{K}^{+}$acumulado na matéria seca foliar, sendo estes valores reduzidos de 25,92 (água de baixa salinidade) a 13,65 mg (água de alta salinidade).

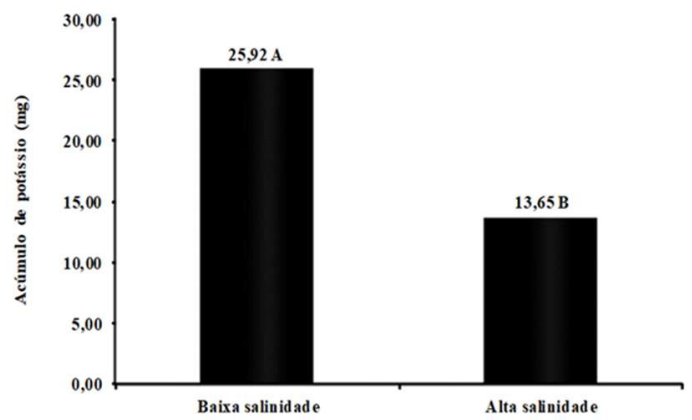

*Médias seguidas de mesmas letras não diferem entre si pelo teste $\mathrm{F}$ a $5 \%$ de significância.

Figura 15. Acúmulo de potássio no tecido foliar de mudas de maracujazeiros submetidas à irrigação com águas salinas.

Figure 15. Potassium accumulation in the leaf tissue of passion fruit seedlings submitted to irrigation with saline water.

Encontra-se na Tabela 7 , o resumo das análises de variância relativas aos teores de acúmulos de $\mathrm{Ca}^{2+}, \mathrm{Mg}^{2+}, \mathrm{S}$ e de $\mathrm{Na}^{+}$.

Tabela 7. Resumo das análises de variância, pelo quadrado médio, referente aos acúmulos de cálcio $\left(\mathrm{ACCa}^{2+}\right)$, de magnésio $\left(\mathrm{ACMg}^{2+}\right)$, de enxofre (ACS) e de sódio $\left(\mathrm{ACNa}^{+}\right)$nos tecidos foliares de mudas de maracujazeiros amarelo e roxo irrigadas com águas salinas e aplicação de urina oxidada de vaca.

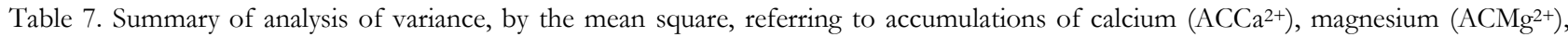
sulfur (ACS) and sodium $\left(\mathrm{ACNa}^{+}\right)$in the leaf tissues of yellow and purple passion fruit seedlings irrigated with saline water and application of oxidized cow urine.

\begin{tabular}{|c|c|c|c|c|c|}
\hline \multicolumn{6}{|c|}{ Quadrados Médios } \\
\hline \multicolumn{6}{|l|}{ Fontes de Variação } \\
\hline & GL & $\mathrm{ACCa}^{2+}$ & $\mathrm{ACMg}^{2+}$ & ACS & $\mathrm{ACNa}^{+}$ \\
\hline Cultivares $(\mathrm{C})$ & 1 & $1245,600^{* *}$ & $45,650^{* *}$ & $33,630^{* *}$ & $17,883^{* *}$ \\
\hline Salinidade (S) & 1 & $316,827^{*}$ & $7,085^{\mathrm{ns}}$ & $10,101^{* *}$ & $72,732^{* *}$ \\
\hline Urina $(\mathrm{U})$ & 1 & $40,456^{\mathrm{ns}}$ & $2,667 \mathrm{~ns}$ & $0,490^{\mathrm{ns}}$ & $9,907^{* *}$ \\
\hline $\mathrm{C} \times \mathrm{S}$ & 1 & $87,020^{\mathrm{ns}}$ & $0,107 \mathrm{~ns}$ & $4,429^{*}$ & $8,283^{*}$ \\
\hline $\mathrm{C} \times \mathrm{U}$ & 1 & $3,667 \mathrm{~ns}$ & $0,035^{\mathrm{ns}}$ & $0,781^{\mathrm{ns}}$ & $2,077^{\mathrm{ns}}$ \\
\hline $\mathrm{S} \times \mathrm{U}$ & 1 & $31,373^{\text {ns }}$ & $0,742^{\mathrm{ns}}$ & $0,055^{\mathrm{ns}}$ & $4,717^{\mathrm{ns}}$ \\
\hline $\mathrm{C} \times \mathrm{S} \times \mathrm{U}$ & 1 & $2,842^{\mathrm{ns}}$ & $0,814^{\mathrm{ns}}$ & $0,017^{\mathrm{ns}}$ & $4,438^{\mathrm{ns}}$ \\
\hline Erro & 16 & 43,888 & 3,838 & 0,556 & 0,992 \\
\hline Total & 23 & & & & \\
\hline $\mathrm{CV}(\%)$ & & 29,1 & 39,3 & 28,6 & 14,9 \\
\hline
\end{tabular}

As cultivares e a salinidade afetaram, estatisticamente, os acúmulos de $\mathrm{Ca}^{2+}$ nos tecidos foliares das mudas (Tabela 7).

Os menores valores médios de acúmulo de $\mathrm{Ca}^{2+}$ nos tecidos foliares foram obtidos nas mudas de maracujazeiroroxo, cerca de $48,1 \%$ inferior ao observado nas mudas de maracujazeiro-amarelo (Figura 16).

As mudas de maracujazeiros apresentaram decréscimos na ordem de $27,5 \%$ do $\mathrm{Ca}^{2+}$ acumulado com a adição de água de condutividade elétrica de $3,5 \mathrm{dS} \mathrm{m}^{-1}$ (Figura 17).

As cultivares de maracujazeiro analisadas, de forma isolada, influenciaram nos resultados dos acúmulos de $\mathrm{Mg}^{2+}$ nos tecidos foliares (Tabela 7).

$\mathrm{O} \mathrm{Mg}^{2+}$ acumulado na matéria seca foliar nas mudas de maracujazeiro-amarelo e roxo foi de 6,37 e 3,61 $\mathrm{mg}$, respectivamente, estando estes resultados coerentes com os apresentados na Figura 12 para o acúmulo de fósforo na planta. A interação cultivares e salinidade exerceu influência estatística nos acúmulos de $\mathrm{S}$ nos tecidos foliares das mudas de maracujazeiro (Tabela 7).

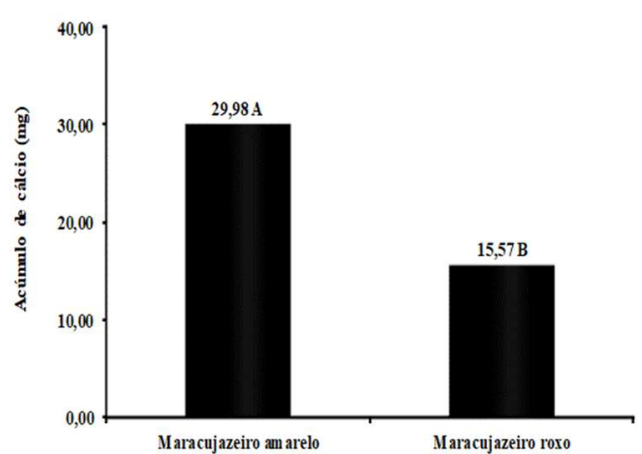

*Médias seguidas de mesmas letras não diferem entre si pelo teste $\mathrm{F}$ a $5 \%$ de significância.

Figura 16. Acúmulo de cálcio no tecido foliar de mudas de maracujazeiro-amarelo e roxo.

Figure 16. Calcium accumulation in the leaf tissue of yellow and purple passion fruit seedlings. 


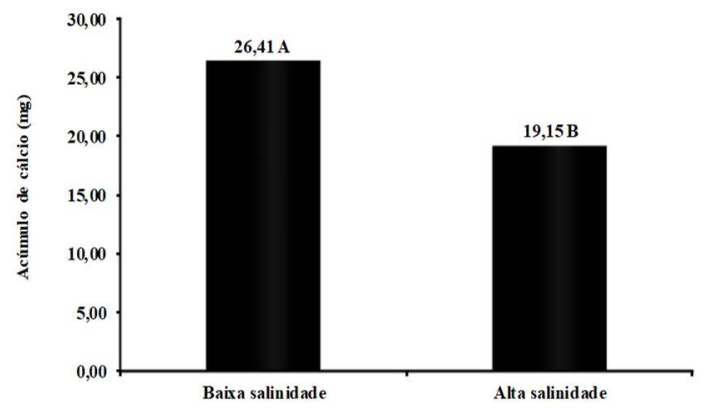

*Médias seguidas de mesmas letras não diferem entre si pelo teste $\mathrm{F}$ a 5\% de significância.

Figura 17. Acúmulo de cálcio na matéria seca foliar de mudas de maracujazeiros submetidas à irrigação com águas salinas.

Figure 17. Calcium accumulation in leaf dry matter of passion fruit seedlings submitted to irrigation with saline water.

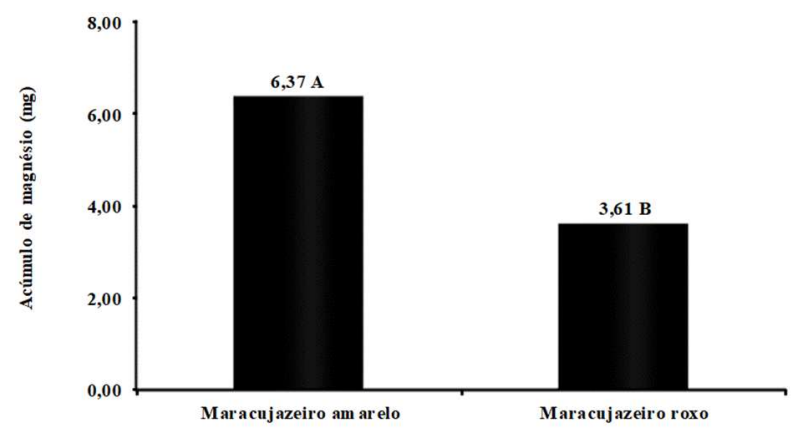

*Médias seguidas de mesmas letras não diferem entre si pelo teste $\mathrm{F}$ a $5 \%$ de significância.

Figura 18. Acúmulo de magnésio na matéria seca de mudas de maracujazeiro-amarelo e roxo.

Figure 18. Magnesium accumulation in the dry matter of yellow and purple passion fruit seedlings.

No tecido foliar das mudas de maracujazeiro-amarelo, independentemente do teor salino da água aplicada às mudas na irrigação, foram verificados valores médios de acúmulo de $\mathrm{S}$, superior ao observado nas mudas de maracujazeiro-roxo, de forma mais proeminente nas plantas irrigadas com água de menor salinidade $(197,0 \%)$. Houve redução de 2,16 mg no acúmulo de enxofre, entre as mudas de maracujazeiroamarelo irrigadas, quando passaram a ser irrigadas com água mais salina.

Na Figura 20, observa-se que, nas mudas fertilizadas com urina de vaca, o acúmulo de $\mathrm{Na}^{+}$nos tecidos foliares foi de $7,29 \mathrm{mg}$ por planta, superior em $21,3 \%$ ao contido no tecido foliar das mudas sem adubação com o insumo.

$\mathrm{O}$ acúmulo de $\mathrm{Na}^{+}$nos tecidos foliares das mudas de maracujazeiro foram afetadas, estatisticamente, pela interação cultivares e salinidade e, de forma isolada, pala aplicação de urina oxidada de vaca (Tabela 7).

Conforme os dados apresentados na Figura 21, semelhante ao observado para o acúmulo de $\mathrm{S}$, independentemente da salinidade da água aplicada às plantas, as mudas de maracujazeiro-amarelo apresentaram maiores valores médios de acúmulos de $\mathrm{Na}^{+}$nos tecidos foliares, de forma mais expressiva com águas de baixa salinidade, com acréscimos de $105,3 \%$.

Nas plantas irrigadas com água de baixa salinidade, no tecido foliar das mudas de maracujazeiro-amarelo foram verificados valores médios de 7,68 $\mathrm{mg}$ de $\mathrm{Na}^{+}$acumulado, inferior em 14,6\% ao acúmulo na mesma espécie sob irrigação com água mais salina.

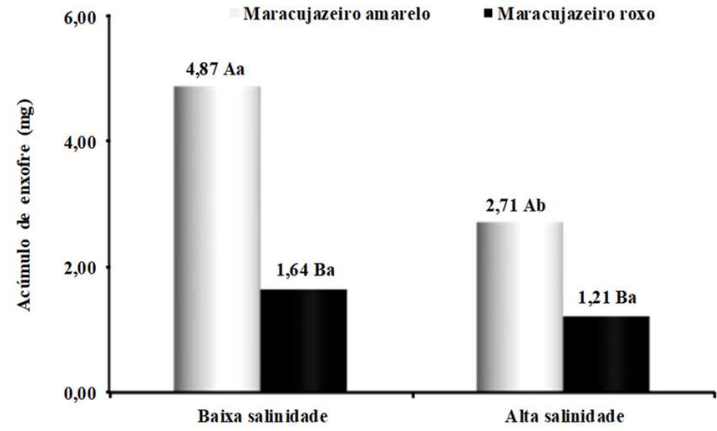

*Médias seguidas de mesmas letras maiúsculas entre diferentes cultivares e na mesma salinidade e minúsculas dentro das mesmas cultivares e diferentes salinidades não diferem entre si pelo teste $\mathrm{F}$ a $5 \%$ de significância.

Figura 19. Acúmulo de enxofre na matéria seca foliar de mudas de maracujazeiro-amarelo e roxo irrigadas com águas salinas.

Figure 19. Sulfur accumulation in leaf dry matter of yellow and purple passion fruit seedlings irrigated with saline water.

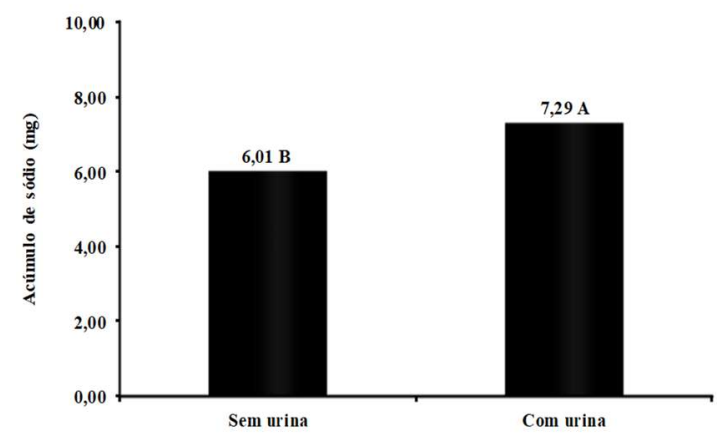

*Médias seguidas de mesmas letras não diferem entre si pelo teste $\mathrm{F}$ a $5 \%$ de significância.

Figura 20. Acúmulo de sódio na matéria seca foliar de mudas de maracujazeiro fertilizadas com urina oxidada de vaca.

Figure 20. Sodium accumulation in leaf dry matter of seedlings passion fruit fertilized with oxidized cow urine.

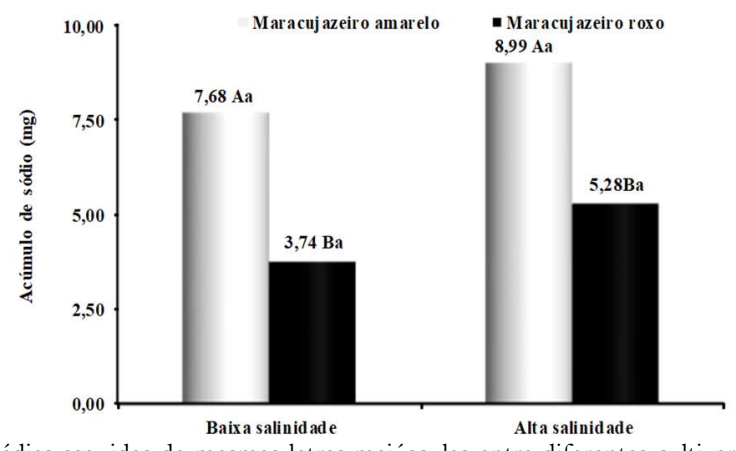

*Médias seguidas de mesmas letras maiúsculas entre diferentes cultivares e na mesma salinidade e minúsculas dentro das mesmas cultivares e diferentes salinidades não diferem entre si pelo teste $\mathrm{F}$ a $5 \%$ de significância.

Figura 21. Acúmulo de sódio na matéria seca foliar de mudas de maracujazeiro-amarelo e roxo irrigadas com águas salinas.

Figure 21. Sodium accumulation in leaf dry matter of yellow and purple passion fruit seedlings irrigated with saline water.

\section{DISCUSSÃO}

A menor absorção de $\mathrm{N}$ pelos tecidos foliares das mudas de maracujazeiro-amarelo, possivelmente seja atribuída à menor expansividade e crescimento radicular desta espécie em comparação ao maracujazeiro-roxo, que, conforme afirmações detalhadas por Fan; Yang (2011) em estudos com maçã, assim como o maracujazeiro, classificada como 
glicófita, influenciam a capacidade de absorção de nutrientes pelas plantas.

$\mathrm{O}$ aumento da salinidade da água de irrigação promoveu elevação no teor de $\mathrm{N}$ no tecido foliar das mudas. Isso pode decorrer de acúmulo de nitratos $\left(\mathrm{NO}^{3-}\right)$ nos vacúolos foliares das plantas, com influência no ajustamento osmótico. Esses nitratos acumulados aliviaram os efeitos do estresse salino, com possível redução no acúmulo de $\mathrm{Cl}^{-}$, além de aumentar os teores de prolina e $\mathrm{N}$-aminossolúveis (FEIJÃO et al., 2013; LIMA et al., 2016).

O estresse salino ocasiona ineficiência na taxa fotossintética, reduzindo, por sua vez, a necessidade energética das plantas, o que poderá resultar, consequentemente, em uma baixa absorção de fósforo (LUCENA et al., 2012). No entanto, a menor concentração do fósforo em plantas irrigadas com águas mais salinas devese à baixa disponibilidade deste elemento na solução do solo, devido à formação de precipitados de cálcio em condições de pH alcalino (HASAN et al., 2016), como se observa nos dados das Tabelas 1 e 2.

Os acréscimos nos teores de $\mathrm{K}^{+}$para ambas as espécies de maracujazeiros entre as plantas irrigadas com água mais salina, ao se aplicar o insumo orgânico, devem-se aos teores de $\mathrm{K}^{+}$existentes na urina oxidada de vaca aplicada (Tabela 1) e absorvida pelas plantas.

Quanto à redução na absorção de $\mathrm{K}^{+}$em condições salinas, independentemente da espécie e da aplicação, ou não, da urina oxidada de vaca, possivelmente, de acordo com Capula-Rodriguez et al. (2006), as mudas de maracujazeiros não foram capazes de promover o ajuste iônico no interior das raízes, possibilitando a absorção do sódio em detrimento do potássio.

Ademais, para Marschner (2012) a redução na concentração de $\mathrm{K}^{+}$nos tecidos foliares em plantas submetidas a estresse salino, relaciona-se ao antagonismo entre este elemento e o $\mathrm{Na}^{+}$por ocasião da absorção de solutos da solução do solo.

Independentemente da espécie de maracujazeiro, os resultados indicam que as plantas apresentaram valores adequados de $\mathrm{Mg}^{2+}$ nos tecidos foliares. Para Scaramuzza et al. (2001) e Natale et al. (2006), as mudas de maracujazeiro são consideradas nutridas em magnésio quando apresentam teores foliares de 1,8 e $2,8 \mathrm{~g} \mathrm{~kg}^{-1}$, respectivamente.

Sousa et al. (2012), avaliando os teores de macronutrientes em mudas de pinhão-manso, sob condições de estresse salino, obtiveram teores médios de $\mathrm{Mg}^{2+}$ de 6,99 $\mathrm{g} \mathrm{kg}^{-1}$, superior em $6,78 \%$ aos observados no tratamento controle $\left(6,51 \mathrm{~g} \mathrm{~kg}^{-1}\right)$, corroborando com os observados neste trabalho.

Como as plantas não estavam supridas adequadamente em $\mathrm{K}^{+}$(Figura 5), isso pode ter ocasionado, em razão da interação, ter contribuído para o suprimento adequado de $\mathrm{Ca}^{2+}$ e $\mathrm{Mg}^{2+}$ nas mudas de maracujazeiro, em razão da competição pelos sítios de absorção e o antagonismo entre ambos (PRADO, 2008; MARSCHNER, 2012).

O S é um elemento mineral essencial ao crescimento e sobrevivência das espécies, pois está relacionado com a formação de determinadas enzimas, além de desempenhar papéis fundamentais no metabolismo fisiológico das plantas, com resposta ao estresse (CAPALDI et al. (2015).

Neste trabalho, os menores valores de $\mathrm{S}$ observados na cultivar de maracujazeiro-roxo, possivelmente estejam relacionados à forma de absorção do $\mathrm{N}$, provavelmente na forma de nitrato. Esta forma de absorção reduz a absorção do S (REICH, 2017). Como os teores de $\mathrm{N}$ no tecido foliar do maracujazeiro-amarelo foram superiores aos das mudas de maracujazeiro-amarelo, há coerência no que se observou para S. Ademais, quanto à mobilidade no floema, os nutrientes $\mathrm{N}$ e $\mathrm{S}$ têm comportamento diferentes, sendo móvel e imóvel, respectivamente.

Os teores de $\mathrm{Na}^{+}$apresentados na Figura 9 justificam os menores valores de atributos de crescimento (alturas das plantas, diâmetro caulinar e área foliar) de mudas de maracujazeiro-roxo, em comparação com as de maracujazeiro-amarelo, informadas por Freire; Nascimento (2018).

Os teores de $\mathrm{Na}^{+}$nos tecidos foliares apresentados foram coerentes com os teores desse elemento presentes no substrato (Tabela 1) e na água de alta salinidade (Tabela 2), o que contribuíram para os resultados observados.

Ademais, e conforme afirmações compiladas por Maathuis (2014), a absorção do sódio é mais efetiva, podendo até ser benéfico para as plantas, quando a do potássio é deficitária. Sendo assim, é possível atestar que, além do excesso de sódio presente na água de irrigação, a limitada absorção do potássio e a competitividade entre estes dois elementos tenham influenciado nos altos teores do sódio no tecido foliar de ambas as espécies de maracujazeiros.

Neste trabalho, embora os maiores teores de $\mathrm{N}$ tenham sido encontrados na cultivar de maracujazeiro-roxo (Figura 11), verificou-se uma menor necessidade de alocação deste elemento na superficie foliar da espécie, acenando para sua alocação em outro órgão, a exemplo da raiz. Kaushik; Djiwanti (2018), em estudos sobre os mecanismos de absorção de nutrientes pelas plantas, enfatizaram a importância das raízes na aquisição de elementos minerais. Conforme os autores, a capacidade de absorção de elementos no solo está diretamente relacionada ao maior volume e área superficial das raízes, sendo este mecanismo variável entre as cultivares.

A absorção de elementos como o fósforo tende a ser positiva quando a presença do nitrato no solo, ou em substratos usados na produção de mudas, é alta, devido aos processos de sinergismos existentes entre o P e o N. Neste ponto, levando em consideração o maior acúmulo de $\mathrm{N}$ pelas mudas de maracujazeiro-amarelo (Figura 11), é de se esperar que durante o processo de absorção de $\mathrm{N}$, e na forma de nitrato, a planta tenha demandado um gasto maior de energia (ATP), necessitando acumular uma quantidade maior de fósforo em seu tecido vegetal (LI et al., 2015) quando comprado com a cultivar de maracujazeiro-roxo.

A redução no acúmulo de $\mathrm{P}$ em plantas sob estresse salino pode decorrer dos efeitos relacionados à força iônica, que reduzem a atividade do fosfato na solução do solo, a elevada adsorção do fosfato e a diminuição da solubilidade desse mineral, em virtude do aumento dos níveis de $\mathrm{Cl}^{-}$e $\mathrm{Na}^{+}$no solo, conforme observado por Carmo et al. (2011) em abobeoreiras irrigadas com águas salinas.

As superioridades percentuais de acúmulos de $\mathrm{K}^{+}$nas mudas de maracujazeiro-amarelo em relação às de maracujazeiro-roxo (107,8\%), conforme Figura 14, e de acúmulo de $\mathrm{Ca}^{2+}$ de $95,7 \%$ (Figura 16), confirmam o antagonismo e à ação competitiva entre esses elementos, pois o menor percentual de $\mathrm{Ca}^{2+}$ no tecido foliar das mudas de maracujazeiro-amarelo indicam uma maior ocupação do elemento $\mathrm{K}^{+}$nos sítios de trocas desta espécie. Isso confirma as afirmações de Prado et al. (2004), Marschner (2012) e Silva; Trevisan (2015). 
Os valores médios de acúmulo de $\mathrm{Ca}^{2+}$ apresentados na Figura 17 divergem dos apresentados pelos autores Cruz et al. (2006), que não observaram efeitos nocivos dos sais sobre a absorção do cálcio em mudas de maracujazeiro-amarelo.

Os valores médios de acúmulo de $\mathrm{Mg}^{2+}$, para cada espécie de mudas de maracujazeiro, são coerentes com os de acúmulo de $\mathrm{P}$ na Figura 12. De acordo com afirmações compiladas por Fageria (2006) e Lange (2007), o $\mathrm{Mg}^{2+}$ participa dos processos de ativação enzimática, sendo capaz de formar pontes entre o ATP e diferentes enzimas. Neste ponto, a absorção de um desses elementos provavelmente deve ter favorecido a absorção do outro, resultando em maior acúmulo de ambos no tecido vegetal das mudas de maracujazeiro-amarelo.

Os relatos sobre o acúmulo de enxofre nos tecidos das plantas cultivadas sob condições de salinidade são bastante limitados. Os estudos, em sua maioria, enfocam os diferentes efeitos ocasionados pela salinidade decorrentes do excesso de sulfatos em relação àqueles ocasionados por cloretos (FERREIRA et al., 2007).

O S participa do processo de formação de diversas enzimas e proteínas, essenciais aos processos fisiológicos e metabólicos das plantas, o que pode vir a atenuar os efeitos nocivos dos sais solúveis (KHAN et al., 2014).

A composição química e o teor salino da urina de vaca $\left(5,7 \mathrm{dS} \mathrm{m}^{-1}\right)$ aplicada às plantas, conforme consta na Tabela 3, favoreceu um maior acúmulo de $\mathrm{Na}^{+}$no tecido foliar das mudas de maracujazeiro, possivelmente em razão da competição, pelos sítios de troca, entre nutrientes essenciais, como o $\mathrm{K}^{+}$e o $\mathrm{Na}^{+}$, principalmente em condições de sais na zona radicular (LOPES et al., 2006).

As menores concentrações de $\mathrm{Na}^{+}$na parte aérea das mudas de maracujazeiro-roxo pode ser considerado, conforme também constatado por Lemes et al. (2018) em plantas de arroz submetidas à salinidade, um indicativo de maior tolerância ao estresse salino, sendo este o resultado da menor absorção ou translocação deste elemento pela planta, já que boa parte do sódio absorvido fica alocado nas raízes, por meio da compartimentalização de íons.

Altas concentrações de íons tóxicos na raiz podem reduzir os efeitos prejudiciais desses elementos sobre as folhas, que são as principais vias responsáveis pela captação de $\mathrm{CO}_{2}$ e dos processos fotossintéticos. Fato é que as folhas das espécies de maracujazeiros analisadas nesta pesquisa não apresentaram efeitos visuais característicos de toxicidade por $\mathrm{Na}^{+}$(RAHNESHAN et al., 2018).

\section{CONCLUSÕES}

A irrigação com águas salinas de até $3,5 \mathrm{dS} \mathrm{m}^{-1}$ produz efeitos negativos nos teores de $\mathrm{P}$ e $\mathrm{Na}^{+}$e positivos na concentração de $\mathrm{N}, \mathrm{Ma}^{2+}$ nos tecidos foliares de mudas de maracujazeiros amarelo e roxo.

Os teores foliares de $\mathrm{N}, \mathrm{Mg}^{2+}$ e $\mathrm{Na}^{+}$em mudas de maracujazeiro-amarelo são superiores aos de maracujazeiroroxo.

A aplicação de urina oxidada de vaca diluída em água a $5,0 \%$ na produção de mudas de maracujazeiros amarelo e roxo irrigadas com águas de elevada salinidade, por apresentar efeitos negativos nos teores de $\mathrm{K}^{+}$nos tecidos foliares, indica que o insumo pode não eliminar os efeitos dos sais às plantas na fase de mudas.
O uso de urina oxidada de vaca afeta, positivamente, os teores foliares de $\mathrm{N}$ em mudas de maracujazeiros.

$\mathrm{O}$ acúmulo dos macronutrientes $\left(\mathrm{P}, \mathrm{K}^{+}\right.$e $\left.\mathrm{Ca}^{2+}\right)$ em folhas de mudas de maracujazeiros é maior quando irrigadas com águas de baixa salinidade.

\section{AGRADECIMENTOS}

À Pro-Reitoria de Pesquisa, Inovação e Pós-Graduação do Instituto Federal da Paraíba e ao CNPq pela concessão de Bolsa - PIBIC.

\section{REFERÊNCIAS}

ARAÚJO, D. L.; OLIVEIRA, R. R.; SOUTO, A. G. L.; CAVALCANTE, L. F.; MELO FILHO, J. S. Urina de vaca como atenuador da salinidade no crescimento e biomassa em plantas de berinjela. Revista Engenharia na Agricultura, Viçosa, v. 27, n. 5, p. 452-461, 2019. DOI: https://dx.doi.org/10.13083/reveng.v27i5.944

ASSAHA, D. V. M.; UEDA, A.; SANEOKA, H. Comparison of growth and mineral accumulation of two solanaceous species, Solanum scabrum Mill. (huckleberry) and S. melongena L. (eggplant), under salinity stress. Journal Soil Science and Plant Nutrition, Tokyo, v. 59, n. 6, p. 912-920, 2013. DOI https://dx.doi.org/10.1080/00380768.2013.858300

BERTANI, R. M. A.; SILVA, S. P.; DEUS, A. C. F.; ANTUNES, A. M.; FISCHER, I. H. Doses de nitrogênio no desenvolvimento de mudas altas de maracujá amarelo. Revista de Agricultura Neotropical, Cassilândia, v. 6, n. 1 , p. 29-35, 2019. DOI: https://dx.doi.org/10.32404/rean.v6i1.2403

CAPALDI, F. R.; GRATÃO, P. L.; REIS, A. R.; LIMA, L. W.; AZEVEDO, R. A. Sulfur Metabolism and Stress Defense Responses in Plants. Tropical Plant Biology, New York, v. 8, n. 3, p. 60-73, 2015. DOI: https://dx.doi.org/10.1007/s12042-015-9152-1

CAPULA-RODRIGUEZ, R.; VALDEZ-AGUILAR, L. A.; CARTMILL, D. L.; CARTMILL, A. D.; ALIATEJACAR, J. A. Supplementary calcium and potassium improve the response of tomato (Solanum bycopersicum L.) to simultaneous alkalinity, salinity, and boron stress. Communications in soil science and plant analysis, New York, v. 47, n. 4, p. 1-7, 2016. DOI: https://dx.doi.org/10.1080/00103624.2016.1141924

CARMO, C. A. F. S.; ARAÚJO, W. S.; BERNARDI, A. C. C.; SALDANHA, . F. C. Métodos de análise de tecidos vegetais utilizados na Embrapa Solos. Rio de Janeiro: Embrapa Solos, 2000. 41 p. (Circular Técnica, 6).

CARMO, G. A.; OLIVEIRA, F. R.; MEDEIROS, J, F.; OLIVEIRA, F. A.; CAMPOS, M. S. Teores foliares, acúmulo e partição de macronutrientes na cultura da abóbora irrigada com água salina. Revista Brasileira de Engenharia Agrícola e Ambiental, Campina Grande, v. 15 , n. 5 , p. 512-518, 2011. DOI: http://dx.doi.org/10.1590/S1415-43662011000500012

CAVALCANTE, L. F.; SOUSA, G. G.; GONDIM, S. C.; FIGUEIREDO, F. L.; CAVALCANTE, I. H. L.; DINIZ, A. A. Crescimento inicial do maracujazeiro amarelo manejado em dois substratos. Irriga, Botucatu, v. 14 , n. 4 , p. 504-517, 2009. DOI: https://dx.doi.org/10.15809/irriga.2009v14n4p504-517 CRUZ, J. L.; PELACANI, C. L.; COELHO, E. F.; 
CALDAS, R. C.; ALMEIDA, A. Q.; QUEIROZ, J. R. Influência da salinidade sobre o crescimento, absorção e distribuição de sódio, cloro e macronutrientes em plântulas de maracujazeiro-amarelo. Bragantia, Campinas, v. 65 , n. 2, p. 275-284, 2006. DOI: https://dx.doi.org/10.1590/S0006-87052006000200009

FAGERIA, V. D. Nutrient interactions in crop plants. Journal of Plant Nutrition, New York, v. 24, n. 8, p. 1269-1290, 2006. DOI: https://doi.org/10.1081/PLN-100106981

FAN, W.; YANG, H. Effect of soil type on root architecture and nutrient uptake by roots of young apple rootstocks. Acta Horticulturae, Bruxelas, v. 903, p. 885-890, 2011. DOI: https://dx.doi.org/10.17660/ActaHortic.2011.903.123

FEIJÃO, A. R.; MARQUES, E. C.; SILVA, J. C. B.; LACERDA, C. F.; PRISCO, J. T.; GOMES-FILHO, E. Nitrato modula os teores de cloreto e compostos nitrogenados em plantas de milho submetidas à salinidade. Bragantia, Campinas, v. 72, n. 1, p. 10-19, 2013. DOI: https://doi.org/10.1590/S000687052013005000021

FERREIRA, D. F. Sisvar: a guide for its bootstrap procedures in multiple comparisons. Ciência e Agrotecnologia, Lavras, v. 38, n. 2, p. 109-112, 2011. DOI: 70542014000200001

FERREIRA, P. A.; GARCIA, G. O.; NEVES, J. L. L.; MIRANDA, G. V.; SANTOS, D. A. Produção relativa do milho e teores folheares de nitrogênio, fósforo, enxofre e cloro em função da salinidade do solo. Revista Ciência Agronômica, Fortaleza. v. 38, n. 1, p. 7-16, 2007.

FILGUEIRAS, R. C.; TAKAHASHI, H. W.; BENINNI, E. R. T. Produção de alface hidropônico em diferentes condutividades elétricas. Semina: Ciências Agrárias, Londrina, v. 23, n. 2, p. 157-164, 2002. DOI: http://dx.doi.org/10.5433/1679-0359.2002v23n2p157

FREIRE, J. L. O.; NASCIMENTO G. S. Produção de mudas de maracujazeiros amarelo e roxo irrigadas com águas salinas e uso de urina de vaca. Revista de Ciências Agrárias, Lisboa, v. 41, n. 4, p. 981-988, 2018. DOI: https://dx.doi.org/10.19084/RCA18164

HASAN, M. M.; HASAN, M. M.; SILVA, J. A. T.; LI, X. Regulation of phosphorus uptake and utilization: transitioning from current knowledge to practical strategies. Cellular \& Molecular Biology Letters, Bethesda, v. 21, n. 7, 2016. DOI: https://dx.doi.org/10.1186/s11658-016-0008-y

IBGE_INSTITUTO BRASILEIRO DE GEOGRAFIA E ESTATÍSTICA. Produção agrícola municipal. 2018. Disponível em: <https://sidra.ibge.gov.br/tabela/839>. Acessado em: 22 de fev de 2020.

KAUSHIK, S.; DJIWANTI, S. R. Genetic improvements of traits for enhancing NPK acquisition and utilization efficiency in plants. In: HOSSAIN, M. A.; KAMIYA, T.; BURRITT, D. J.; TRAN, L.-S. P.; FUJIWARA, T. (Eds.). Plant macronutrient use efficiency. New York: Academic Press, 2017. p. 267-283.

KHAN, N. A.; KHAN, M. I. R.; ASGHER, M.; FATMA, M.; MASOOD, A.; SYEED, S. Salinity Tolerance in Plants: revisiting the role of sulfur metabolites. Plant Physiology and Biochemistry Sectio, Aligarh, v. 2, n. 1, p. 1-8, jan. 2014. DOI: http://dx.doi.org/10.4172/2329-9029.1000120

LANGE, J. L. Suprimento combinado de fósforo e magnésio para a produção e nutrição do capimTanzânia. 2007. 78f. Dissertação (Mestrado) - Programa de Pós-Graduação em Agronomia, Universidade de São Paulo, Piracicaba, 2007.

LAVIOLA, B. G.; DIAS, L. A. S. Teor e acúmulo de nutrientes em folhas e frutos de pinhão-manso. Revista Brasileira de Ciência do Solo, Viçosa, v. 32, n. 5, p. 1969-1975, 2008. DOI: https://doi.org/10.1590/S010006832008000500018

LEMES, E. S.; OLIVEIRA, S.; NEVES, E. H.; RITTER, R.; MENDONÇA, A. O. Crescimento inicial e acúmulo de sódio em plantas de arroz submetidas à salinidade. Amazonian Journal of Agricultural and Environmental Sciences, Belém, v. 61, p. 1-9, 2018. DOI: http:/ /dx.doi.org/10.22491/rca.2018.2764

LI, M.; SHI, X.; LIN, L.; LIN, S. Effects of phosphorus deficiency and adenosine 5'-triphosphate (ATP) on growth and cell cycle of the dinoflagellate Prorocentrum donghaiense. Harmful Algae, Amsterdam, v. 47, p. 35-41, jul. 2015.2 DOI: http:/ /dx.doi.org/10.1016/j.hal.2015.05.013

LIMA, G. S. L.; GHEYI, H. R.; LUAN, D. O.; LAURIANE, A. A. S. Cultivation of colored cotton irrigated with saline water under potassium and nitrate/ammonium fertilization. African Journal of Agricultural, Abuja, v. 11, n. 1, p. 32-39, 2016. DOI: https://dx.doi.org/10.5897/AJAR2015.10540

LOPES, J. L.; PELACANI, C. R.; COELHO, E. F.; CALDAS, R. C.; ALMEIDA, A. Q.; QUEIROZ, J. R. Influência da salinidade sobre o crescimento, absorção e distribuição de sódio, cloro e macronutrientes em plântulas de maracujazeiro-amarelo. Bragantia, Campinas, v. 65, n. 2, p. 275-284, 2006. https://doi.org/10.1590/s0006-87052006000200009

LUCENA, C. C.; SIQUEIRA, D. L.; MARTINEZ, H. E. P.; CECON, P. R. Efeito do estresse salino na absorção de nutrientes em mangueira. Revista Brasileira de Fruticultura, Jaboticabal, v. 34, n. 1, p. 297-308, 2012. DOI: https://dx.doi.org/10.1590/S010029452012000100039

MAATHUIS, F. J. M. Sodium in plants: perception, signalling, and regulation of sodium fluxes. Journal of Experimental Botany, Oxford, v. 65, n. 3, p 849-858, 2014. DOI: https://dx.doi.org/10.1093/jxb/ert326

MALAVOLTA, E.; VITTI, G. C.; OLIVEIRA, S. A. Avaliação do estado nutricional das plantas: princípios e aplicações. 2. ed. Piracicaba: POTAFÓS, 1997. $319 \mathrm{p}$.

MARSCHNER, P. Mineral Nutrition of higher plants. 3. ed. Sidney: Elsevier, 2012. 672 p. DOI: https://dx.doi.org/10.1016/C2009-0-63043-9

MIYAKE, R. T. M. Nitrogênio, fósforo e potássio no estado nutricional, produtividade e qualidade do maracujazeiro-amarelo. Presidente Prudente: UNOESTE, 2016. 124f. Tese (Doutorado) - Programa de Pós-Graduação em Agronomia, Universidade do Oeste Paulista, Presidente Prudente, SP, 2016.

NATALE, W., PRADO, R. M.; BARBOSA, J. C. Adubação nitrogenada e potássica no estado nutricional de mudas de maracujazeiro-amarelo. Acta Scientiarum Agronomy, Santa Maria, v. 28, p. 187-192, 2006. DOI: http:/ /dx.doi.org/10.4025/actasciagron.v28i2.1036 
OLFA, B.; MAHA, Z.; NADA, B.; ZEINEB, O. A. Effects of $\mathrm{NaCl}$ on plant growth and antioxidante activities in fenugreek (Trigonella foenum graecum L.). Bioscience Journal, Uberlândia, v. 34, n. 3, p. 683-696, 2018. DOI: https://doi.org/10.14393/BJ-v34n3a2018-38069

ONODERA, M.; NAKAJIMA, T.; NANZYO, M.; TAKAHASHI, T.; XU, D.; HOMMA, K. Crop physiology regulation of root-to-leaf $\mathrm{Na}$ and $\mathrm{Cl}$ transport and its association with photosynthetic activity in salttolerant soybean genotypes. Journal Plant Production Science, Tokyo, v. 22, n. 2, p. 262-274, 2019. DOI: https://dx.doi.org/10.1080/1343943X.2018.1561198

OYENTUNJI, O. J.; IMADE, F. N. Effect of different levels of $\mathrm{NaCl}$ and $\mathrm{Na}_{2} \mathrm{SO}_{4}$ salinity on dry matter and ionic contents of cowpea (Vigna unguiculata L. Walp). African Journal of Agricultural Research, Lagos, v. 10, n. 11, p. 1237-1243 2015.

DOI: https://dx.doi.org/10.5897/AJAR2014.9463

PESAGRO. Urina de vaca: alternativa eficiente e barata. Seropédica: Pesagro. 2002. 8 p. (Documentos, n. 96).

PIRES, M. M.; GOMES, A. S.; MIDLEJ, M. M. B. C.; SÃO JOSÉ, A. R.; ROSADO, P. L.; PASSOS, H. D. B. Caracterização do mercado de maracujá. In: PIRES, M. M.; SÃO JOSÉ, A. R.; CONCEIÇÃO, A. O. (Org.). Maracujá: avanços tecnológicos e sustentabilidade. Ilhéus: Editus, 2011. p. 21-67.

PRADO, R. M.; BRAGHIROLLI, L. F.; NATALE, W.; CORRÊA, M. C. M.; ALMEIDA, E. V. Aplicação de potássio no estado nutricional e na produção de matéria seca de mudas de maracujazeiro-amarelo. Revista Brasileira de Fruticultura, Jaboticabal, v. 26, n. 2, p. 295-299, 2004. DOI: https://dx.doi.org/10.1590/S010029452004000200028

PRADO, R. M. Nutrição de plantas. São Paulo: UNESP, 2008. $407 \mathrm{p}$.

RAHNESHAN, Z.; NASIBI, F.; MOGHADAM, A. A. Effects of salinity stress on some growth, physiological, biochemical parameters and nutrients in two pistachio (Pistacia vera L.) rootstocks. Journal of Plant Interactions, v. 13, n. 1, p. 73-82, 2018. DOI: https://dx.doi.org/10.1080/17429145.2018.1424355
REICH, M. The significance of nutrient interactions for crop yield and nutrient use efficiency. In: HOSSAIN, M. A. et al. (Eds.). Plant macronutrient use efficiency. New York: Academic Press, 2017. p. 65-82. DOI: https://dx.doi.org/10.1016/B978-0-12-8113080.00004-1

RICHARDS, L. A. Diagnostico y rehabilitación de suelos salinos y sódicos. México: Instituto Nacional de investigaciones agrícolas, 1954. 174 p. (Manual de Agricultura, 60).

SANTOS, H. G.; JACOMINE, P. K.; ANJOS, L. H. C.; OLIVEIRA, V. A. Sistema brasileiro de classificação de solos. 5. ed. Brasília: Embrapa Solos, 2018. 518 p.

SCARAMUZZA, F. F.; COSTA, A. F.; MARTINEZ, H. E. P.; PEREIRA, P. R. G.; FONTES, P. C. R. Deficiências de macronutrients em mudas de maracujazeiro-amarelo em solução nutritiva. Revista Ceres, Viçosa, v. 58, n, 279 , p. 517-527, 2001

SCHOSSLER, T. R.; MACHADO, D. M.; ZUFFO, A. M.; ANDRADE, F. R.; PIAULINO, A. C. Salinidade: efeitos na fisiologia e na nutrição mineral de plantas. Enciclopédia Biosfera, Goiânia, v. 8, n. 15, p. 1563 1578, 2012.

SILVA, M. L. S.; TREVIZAM, A. R. Interações iônicas e seus efeitos na nutrição de plantas. Informações Agronômicas, Piracicaba, n. 149, p. 10-16, 2015.

TANAKA, H.; YAMADA, S.; MASUNAGA, T.; YAMAMOTO, S.; TSUJI, W.; MURILLO-AMADOR, B. Comparison of nutrient uptake and antioxidative response among four Labiatae herb species under salt stress condition. Journal Soil Science and Plant Nutrition, Tokyo, v. 64, n. 5, p. 589-597, jul. 2018. DOI: https://dx.doi.org/10.1080/00380768.2018.14923 34

TEIXEIRA, P. C.; DONAGEMMA, G. K.; FONTANA, A.; TEIXEIRA, W. G. Manual de métodos de análise do solo. 3. ed. rev. e aum. Brasília: Embrapa Solos, 2017. 574 p. 